\title{
APPROACHES FOR CHEMICAL SYNTHESIS AND DIVERSE PHARMACOLOGICAL SIGNIFICANCE OF PYRAZOLONE DERIVATIVES: A REVIEW
}

\author{
MOHAMMAD ASIF ${ }^{1}$ MOHD IMRAN ${ }^{2}$ AND ASIF HUSAIN ${ }^{3}$ \\ ${ }^{I}$ Department of Pharmacy, Himalayan Institute of Pharmacy and Research, Dehradun, (Uttarakhand), 248007, India. \\ ${ }^{2}$ Department of Pharmaceutical Chemistry, Faculty of Pharmacy, Northern Border University, Rafha 91911, PO Box 840, Saudi Arabia. \\ ${ }^{3}$ Department of Pharmaceutical Chemistry, Faculty of Pharmacy, Jamia Hamdard University, New Delhi, India.
}

\begin{abstract}
Pyrazolone is a five-membered lactam ring containing two Nitrogens and one ketonic group in its structure. Numerous pyrazolone derivatives were exhibited with diverse biological, pharmacological, and chemical applications. When pyrazolones were discovered, they were only known as NSAIDs but in recent times they play a versatile role in several complications like cerebral ischemia, cardiovascular diseases, antibacterial, antioxidant, anticancer and several other pharmacological activities. Over the last few decades, pyrazolone derivatives have been used for various biochemical applications. Some of these derivatives such as metamizole, phenazone, aminopyrine, and propyphenazone, are widely used as anti-inflammatory and analgesics. The chemistry of pyrazolone has gained increasing attention due to its diverse pharmacological properties such as anticancer, analgesic, anti-inflammatory, antimicrobial, antioxidant, antifungal, antiviral, antidiabetic, and several other biological activities. Thus, keeping because of their importance, synthetic strategies for existing as well as novel pyrazolone derivatives have been developed and explored their biochemical utility. This review deals with the various pharmacological properties of different pyrazolone derivatives and puts chemical synthetic schemes.
\end{abstract}

Keywords: Pyrazolones, biological activities, antidiabetic, antimicrobial, anti-inflammatory, cardioprotective, antioxidant, anticancer, heterocyclic compounds.

\section{INTRODUCTION}

Heterocyclic compounds represent an important class of biologically active molecules. Moreover, various heterocyclic and biologically active compounds have five-member nitrogen, sulfur, oxygen-containing heterocyclic ring [1]. Pyrazolones have acquired versatile importance as drug substances in the pharmaceutical industry of their biological importance. Pyrazolone is a five-membered lactum ring, containing two nitrogen and one ketonic group in its structure [2]. The 3-pyrazolone (1) and 5-pyrazolone (2) are the most dominant classes having importance in the pharmaceutical industry due to their bio-activity (Figure-1). Compounds containing the pyrazolone nucleus have been shown to possess high biological activities such as tranquilizing, muscle relaxant, psycho analeptic, anticonvulsant, antihypertensive, antidepressant activities [3-10]. The derivatives of pyrazolone are an important class of antipyretic and analgesic compounds. Some substituted pyrazolines and their derivatives are used as antitumor, antibacterial, antifungal, antiviral, anti-parasitic, anti-tubercular, and insecticidal agents [11-15].

For instance, various pyrazolones drugs, viz. phenazone, propyphenazone, ampyrone, and metamizole are useful antipyretic and analgesic drugs [16]. Therefore, pyrazolones possess antimicrobial, antifungal [17], antimycobacterial [18,19], antibacterial [20], anti-inflammatory [21], antitumor [22], gastric secretion stimulatory [23], antidepressant [24], and antifilarial activities [25]. Many attempts have been made to synthesize, characterize, and to study the biological activity of pyrazolones [26]. Interests in the chemistry of organic photochromic compounds containing pyrazolone-ring were tested for their photochromic properties and these compounds exhibited good antibacterial activities [27].
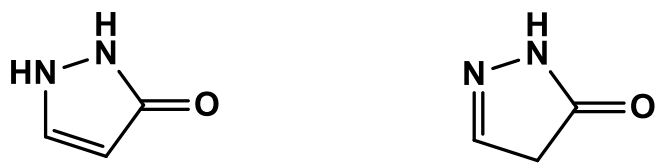

Figure-1. Chemical structures and electrostatic surfaces of 3- and 5pyrazolone

The structure I, is present in several substituted pyrazolones which are widely known and used as antipyretic agents. All these compounds are characterized by the presence of a phenyl group attached to the nitrogen atom in the 1 - position and a methyl group in 3-position. Phenyl group in 1- position and a methyl group in 3-position seem to be essential for antipyretic activity. Several 4, 4-dimethyl derivatives, as well as Pyrazole Blue and Tartrazine, are derived from formula II whereas from structure III several pyrazolone dyes have been derived [28].

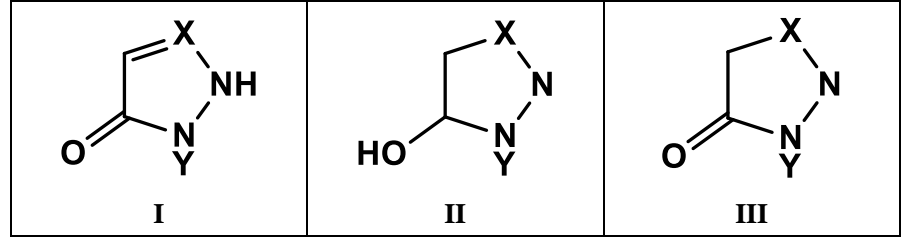

The late 19th century gave rise to the discovery of the three prototypes of modern nonopioid antipyretics and analgesics such as acetaminophen, acetylsalicylic acid, and phenazone [29]. The Chemistry of pyrazolone began in 1883 when Knorr reported the first pyrazolone derivative. The reaction of phenylhydrazine and ethyl acetoacetate resulted in a novel structure identified in 1887 as 1-phenyl-3-methyl-5-pyrazolone [30]. The Knorr pyrazole synthesis is the reaction of hydrazines with 1,3-dicarbonyl compounds to provide the pyrazole or pyrazolone ring system. Pyrazolone is a five-membered lactam ring containing two nitrogen and a ketone group in its ring. The prototype molecule, antipyrine was synthesized for clinical use in 1883 . The methylated nitrogen derivative aminopyrine was introduced in 1897 and taken off from the market in the 1970s because of its property to form nitrosamines. Dipyrone had been in clinical use since 1922. Antipyrine was the first pyrazolone derivative as a drug introduced in 1887 and as the name implies it was the first agent to reduce fever and used in the treatment of arthritis, musculoskeletal and joint disorder. These derivatives were widely used in medical practice viz antipyrine, aminopyrine, analgin, etc. This discovery initiated the beginnings of the great German drug industry that dominated the field for about 40 years. Several pyrazolone derivatives with other heterocyclics were exhibited different types of biological activities [31].

Compounds like 3-Alkyl-4-arylmethylpyrazol-5-ones are reported to exhibit potent antihyperglycemic activity, while 1-phenyl-3-tetrafluoroethylpyrazol-5one is an anxiolytic. Thus, the biological activities of pyrazol-5-ones depend upon the nature of the substituents [32]. 3-methyl-1-phenyl-2-pyrazolin-5-one (Edaravone), a strong free radical scavenger is used for the treatment of patients with acute brain infarction [33]. Demethylated antipyrine is a novel potent free radical scavenger that has been clinically used to reduce the neuronal damage following ischemic stroke. Demethylated antipyrine exerts neuroprotective effects by inhibiting endothelial injury and by ameliorating neuronal damage in brain ischemia. The pharmacological spectrums of pyrazolone compounds are very similar to that of aspirin and some other nonsteroidal anti-inflammatory agents. The drugs containing pyrazolone nucleus are known to display diverse pharmacological activities such as antibacterial, antifungal, anti-inflammatory, analgesic, and antipyretic. The pyrazolone nucleus has been known to exist in three tautomeric structures [34]. The synthesis of 5-substituted-2-[2-(2- 
substituted-10Hphenothiazin-10-yl)-2-oxoethyl]-2,4-dihydro-3H-pyrazol-3one containing phenothiazine were evaluated for their antiproliferative activity [35]. In the recent years, the chemistry and antibacterial activity of pyrazolone have been investigated and synthesized to be novel pyrazolones from easily available starting materials and their broad range of antimicrobial and anti-inflammatory activity were evaluated [36-40]. The study was aimed at exploring our synthesis of some new biologically active pyrazolone derivatives by the reaction of thiosemicarbazide and ethyl-2-chloro acetoacetate.

Table 1. Pyrazolone derivatives available in the market.

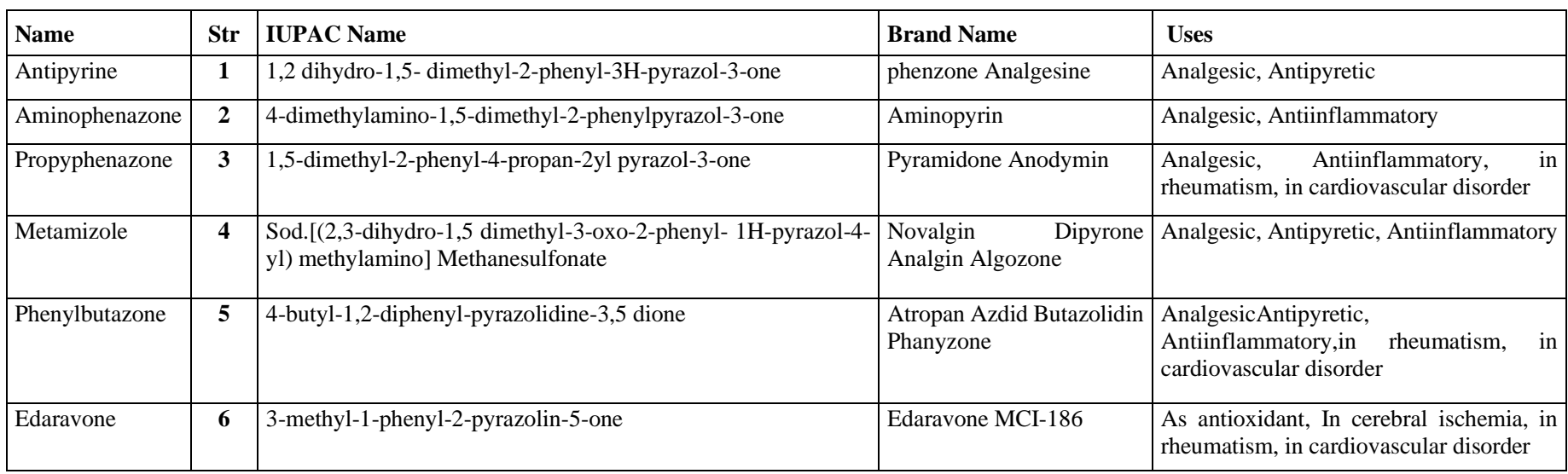

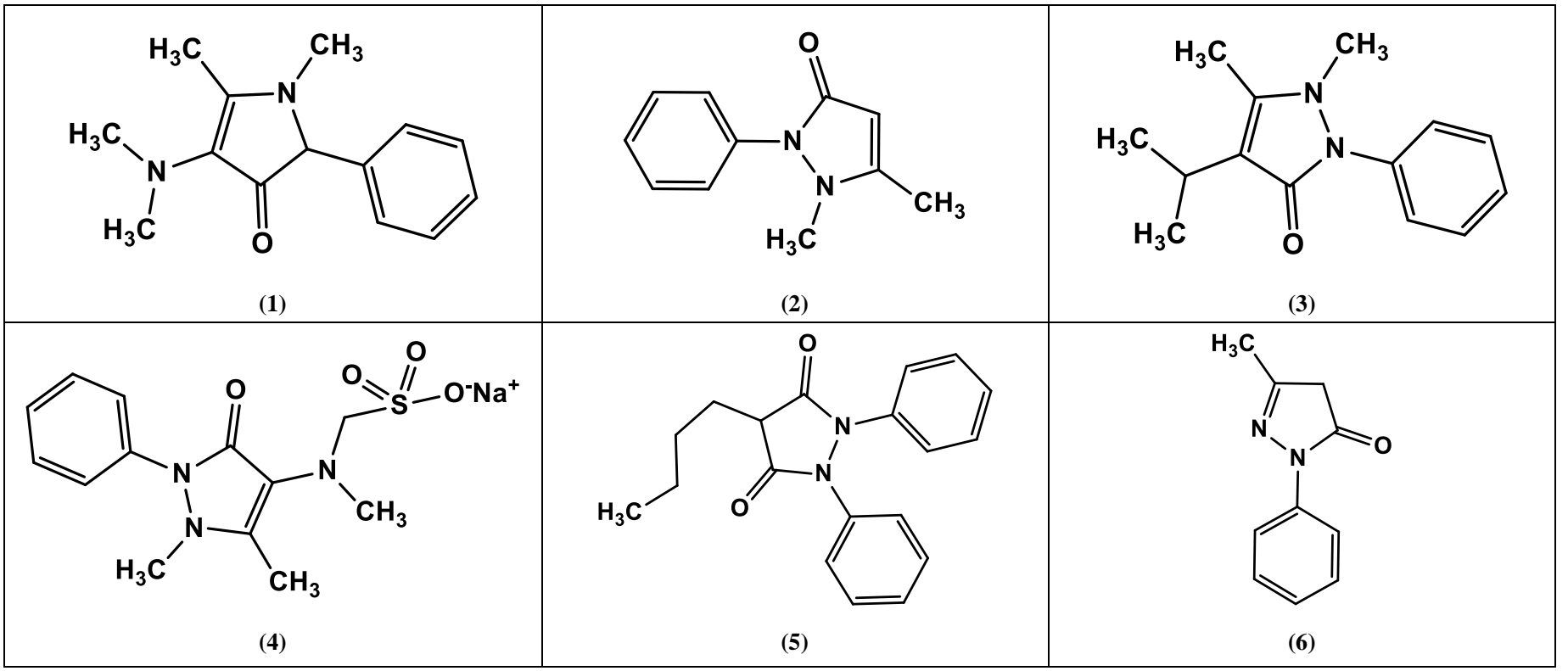

\section{Pharmacological activities of pyrazolones derivatives}

The pyrazolone derivatives like ampyrone, phenazone, and propylphenazone are well known for their antipyretic and analgesic activities. Edaravone has been used for treating brain ischemia [41] and myocardial ischemia [42]. Some novel pyrazolones have been possessed antimicrobial [43], analgesic, antiinflammatory, antipyretic [44], antimycobacterial [45], anticancer [46], gastric secretion stimulatory [47], anticonvulsant [48] and antimalarial activities [49]. Pyrazolones are used as starting materials for the synthesis of commercial aryl/heteroaropyrazolone dyes [50,51]. Halogenated pyrazolones displayed bioactivities as a potent catalytic inhibitor of human telomerase [52] and as fungicide [53]. Pyrazolones have also been shown anti-HIV [54], anti-diabetic [55], anti-hyperlipidemic [56] and immunosuppressive activity [57].

\section{Anticancer activity}

A series of (z)-5-amino-4-[2-(6-bromo-1,3-benzothiazol-2-yl)hydrazinylidene]-2,4dihydro-3H-pyrazol-3-one derivatives (1) were tested for their cytotoxic activity. These compounds had shown prominent cytotoxic activity [58]. Some pyrazolone derivatives (2) from ciprofloxacin and were tested for their cytotoxic activity and it was found that these compounds had shown potential cytotoxic activity against brine shrimp nauplii than ciprofloxacin [59]. The brominated 5methyl-2,4-dihydropyrazol-3-one and its derivatives were exhibited significant cytotoxic activity [60].

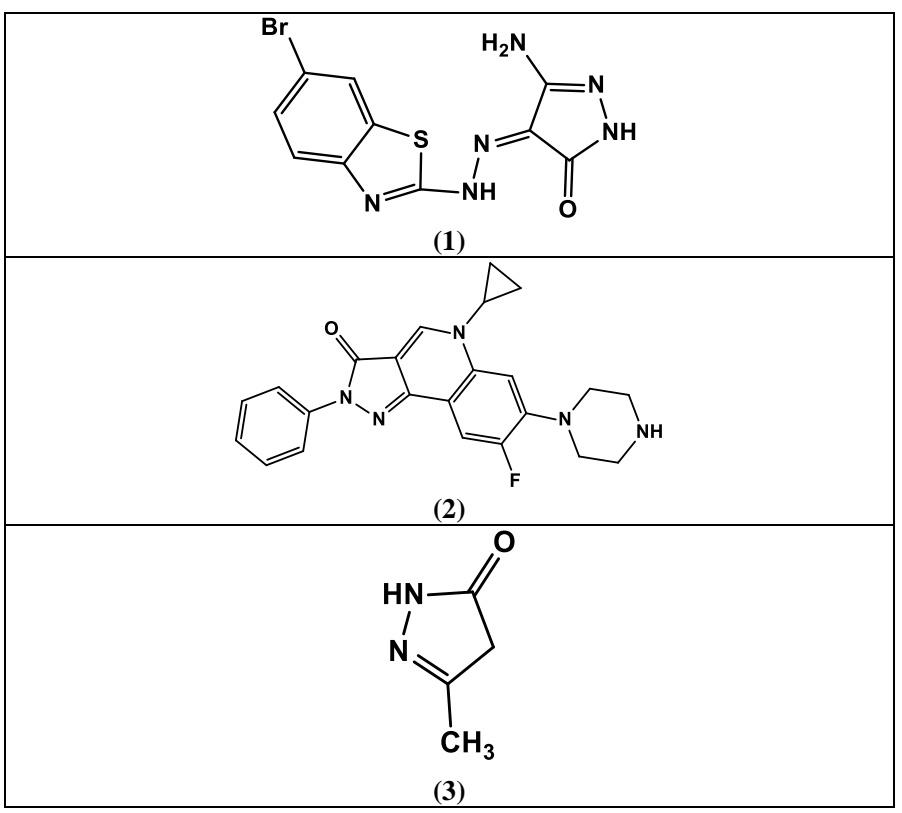


In 2004, several 3-methyl-4-oximinopyrazolin-5-one (4) scaffold which was found to be Cdc25B inhibitor, out of which 3-Methyl-4-( $O$-methyl-oximino)-1phenylpyrazolin-5-one (5) and 1,3-dimethyl-4-( $O$-propargyl oximino)pyrazolin-5-one (6) were found to be most potent. The activity decreases when phenyl group at 1-position was modified to bigger aromatic groups [61,62]. A derivative of 1-phenyl-3-methyl-5-pyrazolone (7), 4,4-dichloro-1-(2,4-dichloro phenyl)-3-methyl-5-pyrazolone (8), named TELIN, was identified as a potent inhibitor of human telomerase in the cell-free telomeric repeat amplification protocol. It inhibits the telomerase activity at the submicromolar level with $\mathrm{IC}_{50}$ of $0.3 \mu \mathrm{M}$. The binding to telomerase protein and the mode of inhibition by this substance was competitive-non-competitive mixed-type concerning the TS primer, whereas it was uncompetitive or noncompetitive-uncompetitive mixed type concerning the three deoxyribonucleosides. TELIN is a potent catalytic blocker of telomerase and is considered to be an important compound for the treatment of cancer and related diseases [63].

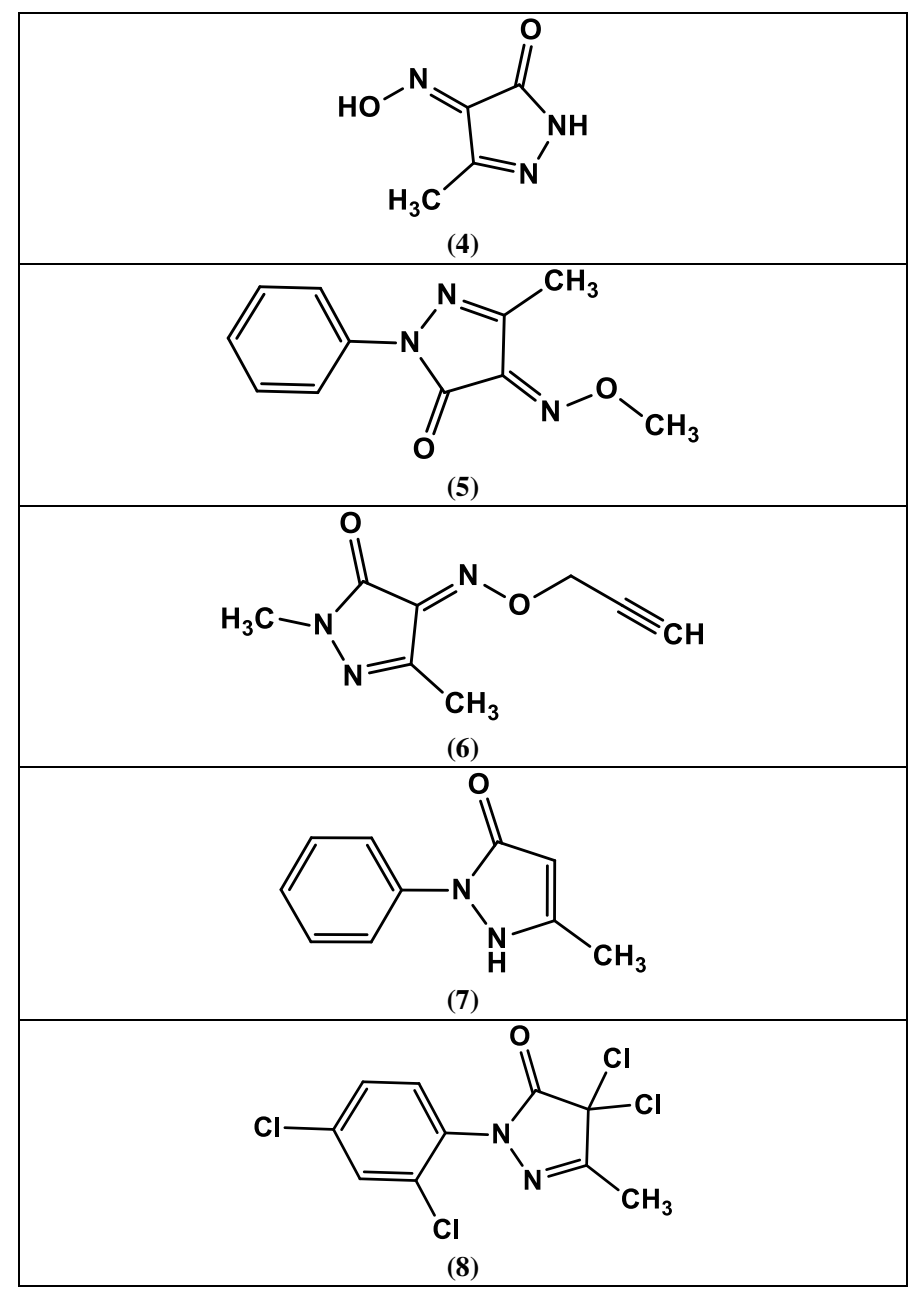

\section{Antimicrobial activity}

The (4Z)-2-(2,4-dinitrophenyl)-4-[(6-methoxynaphthalen-2-yl)methylidene]5-methyl-2,4-dihydro-3H-pyrazol-3-one (9) and (4Z)-4-[(6-methoxynaphthalen2-yl)methylidene]-5-methyl-2-phenyl-2,4-dihydro-3H-pyrazol-3-one (10) were exhibited antimicrobial activity [40].<smiles>COc1ccc2cc(/C=C3\C(=O)N(c4ccc([N+](=O)[O-])cc4[N+](=O)[O-])N=C3C)ccc2c1</smiles>

(9)

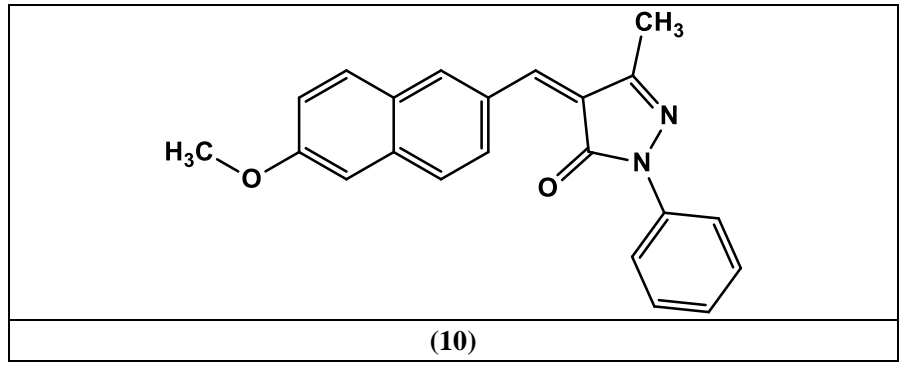

A series of 4-chloro-3-methyl- $N$-(substituted phenyl)-5-oxo-4,5-dihydro- $1 H$ pyrazole-1-carbothioamide compounds (11a-d) were tested for their potent antifungal activity against three fungal pathogens viz A. niger, C. albicans and Curvularia and fluconazole were used as standard drug. All compounds exhibited good to moderate activity. Compounds 11a and 11b were assigned to inhibit the growth of $A$. niger and $C$. albicans, respectively, compounds $11 \mathbf{c}$ and 11d exhibited remarkable inhibition on Curvularia, respectively. The presence of an electron-withdrawing group on the aromatic ring of thiosemicarbazide increases the antifungal activity of tested compounds. Here, the electrondonating group also showed moderate activity against tested pathogens such as A. niger, C. albicans, and Curvularia. All these compounds exposed better antifungal activities against a wide range of microorganisms [64].

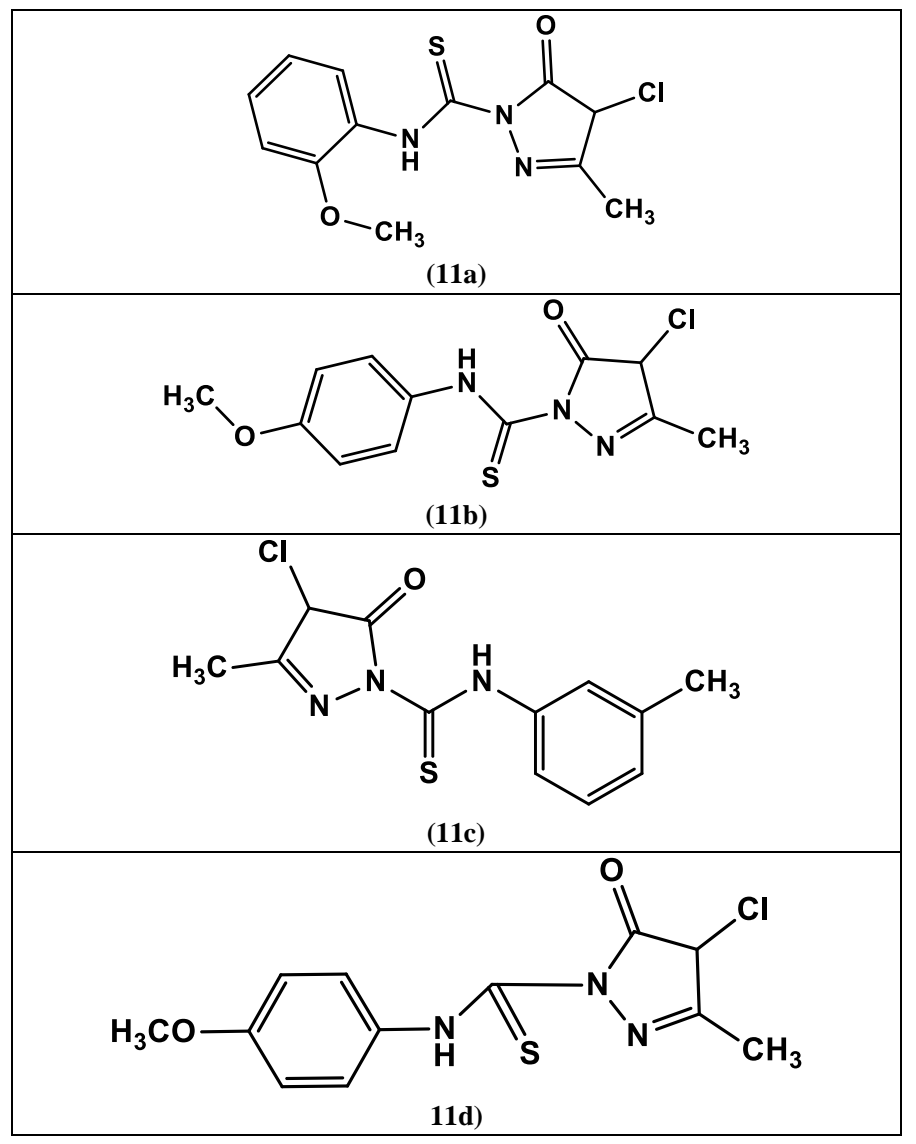

A series of 4-arylhydrazono-2-pyrazoline-5-ones were tested in vitro against one Gram-positive and two Gram-negative bacterial strains, two mycobacterial strains, and a fungus, $C$. albicans. These compounds were found to be more active against $S$. aureus than the other compounds at a concentration of $15.6 \mu \mathrm{g} / \mathrm{mL}$ [65]. The synthesis of $\mathrm{Cu}$ (II) complexes derived from Schiff base ligands formed by the condensation of 2-hydroxybenzaldehyde or terephtalic aldehyde with 4-aminoantipyrine, 4-amino-2,3-dimethyl-1-phenyl-3-pyrazolin5-one (12) was tested for antimicrobial activity and all these complexes are very active, especially against samples of $P$. aeruginosa, A. Boumanii, E. coli, and $S$. aureus [66]. Various 1-isonicotinyl-3-methyl-4-(substituted phenyl hydrazono)-2-pyrazolin-5-one compounds (13) were tested for their antibacterial activity [67]. Various pyrazolone derivatives, 3-phenyl-1H-pyrazol-5(4H)-one (14) were exhibited fungicidal activity [68]. 


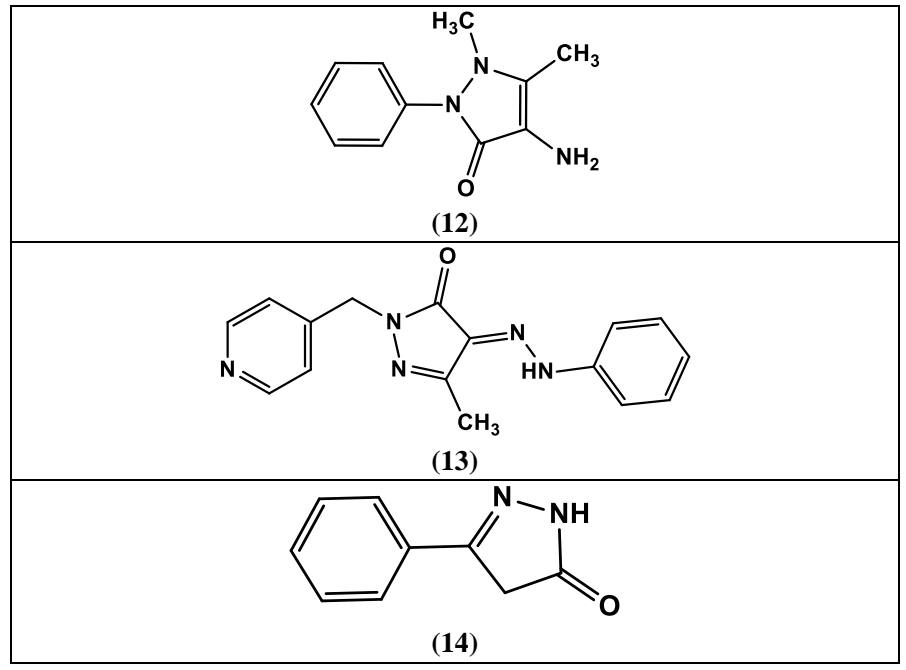

\section{Antioxidant activity}

It has been proved that the pyrazolone derivatives have significant antioxidant activity. The 5-amino-4-[2-(6-bromo-1,3-benzothiazol-2-yl) hydrazinylidene]2,4-dihydro-3H-pyrazol-3-one derivatives (15) were exhibited good antioxidant activity [69]. Some 5-pyrazolone based Schiff bases by the condensation of 4-acylpyrazolone with different aromatic diamines (16) were exhibited significant antioxidant activity [70].

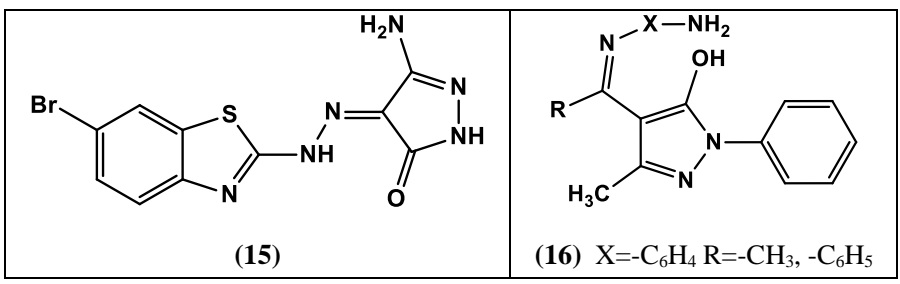

The 3-methyl-1-phenyl-2-pyrazolin-5-one (17, Edaravone) is a strong free radical scavenger. It reduces or restores the amount of ROS increased by postischemic reperfusion and prevents impairment of the antioxidant defense system [71]. The antioxidant action of edaravone is as follows- an electron transfer from an edaravone anion to peroxyl radical yields an edaravone radical and peroxyl anion, and this reaction breaks the chain oxidation of lipids. Then, edaravone peroxyl radical transforms to 4,5-dione by the elimination of a hydrogen atom and one electron. Finally, 2-oxo-3-(phenylhydrazono)-butanoic acid (18, OBP) is produced by the hydrolysis of 4,5-dione [72].

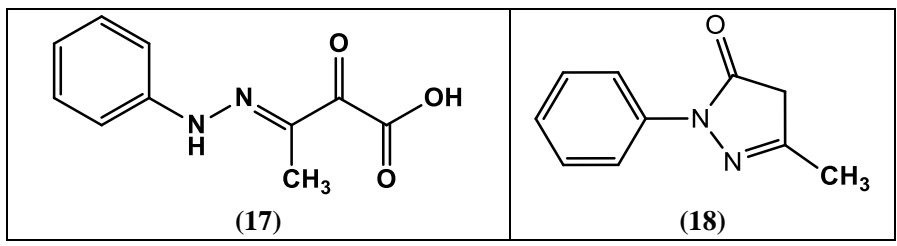

\section{Structure-Activity Relationship (SAR)}

Sterically small substituents like hydrogen and methyl group did not show any activity, substituents containing carbocyclic moieties like cyclohexyl, naphthyl, and benzyl maintained or increased the in vitro lipid peroxidation-inhibitory activity.

- The activity of 2-substituted compounds largely reduced except for a phenolic hydroxyl derivative.

- The activity is increased by the lipophilic substituents like alkyl and halogen. Longer alkyl and alkoxy chains show an increase in activity.

- A disubstituted halogen derivative increases activity as compared with monosubstituted halogen derivatives.

- The introduction of hydrophilic substituents appreciably reduced the activity. A phenyl derivative exhibited excellent activity which was far better than that of a 2-furyl derivative having the lipophilic aromatic group.
- The isobutyl group was exhibited increased activity in contrast to the 2-hydroxyethyl group which showed almost no inhibitory activity.

- The 4,4-Disubstituted compounds showed no inhibitory activity, which supports the hypothesis that compounds which generate the aromatic hydroxyl group by the keto-enol tautomerization have lipid peroxidationinhibitory activity.

\section{Anti-inflammatory, analgesic, and antipyretic activity}

Phenylbutazone, a pyrazolone drug is useful in the treatment of acute gout, rheumatoid arthritis, and allied disorders. A series of pyrazolone derivatives with imidazole, benzimidazole, and benzotriazole moiety (19-21) were tested for their anti-inflammatory activity and the pyrazolone derivatives with benzimidazole were exhibited significant anti-inflammatory activity [73].

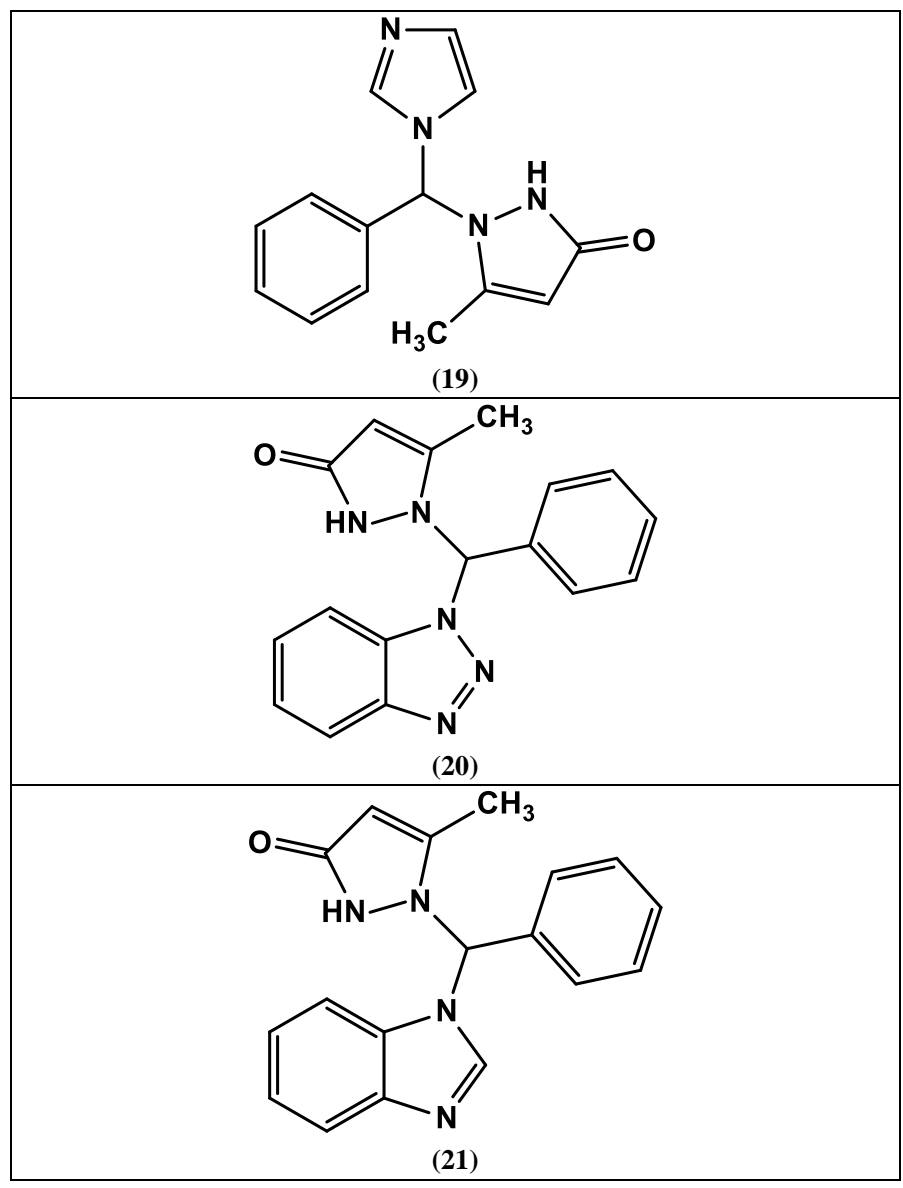

The 3-methyl-4-substituted benzylidene-pyrazol-5-one derivatives (21) were tested for their anti-inflammatory activity. These compounds had shown good anti-inflammatory activity [74]. The 3-methyl pyrazol-5-one derivatives diclofenac, ibuprofen, flurbiprofen were found that the most of the compounds were tested for their analgesic activity [75]. The 3-methyl-4-substituted benzylidene-pyrazol-5-one derivatives (22) were tested for their analgesic activity. These compounds had shown prominent analgesic activity [76].

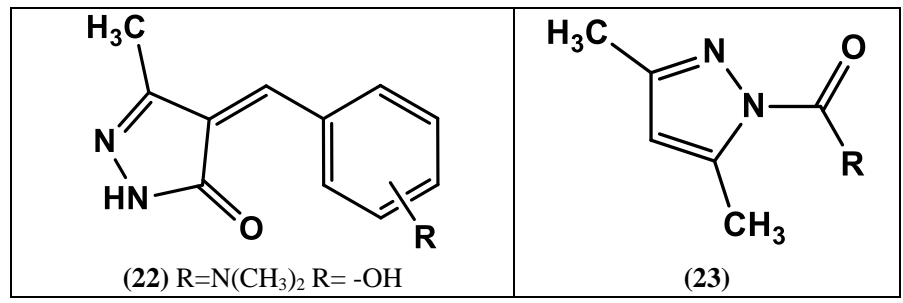

The 4-acetyl-1-phenyl-3-methyl pyrazolone (24, HAP) and 4-trifluroacetyl-1phenyl-3-methyl pyrazolone (25, HTFP) significantly reduces the inflammation in rats [77]. The selective inhibition of Phospholipase A2 is crucial in the search for a efficient anti-inflammatory drug with fewer side effects. 
Dipyrone as well-known pyrazolone inhibitor having anti-inflammatory activity is strongly found to be linked to PLA2s through three hydrogen bonds whereas 1-phenyl-3-methyl-5-pyrazolone (18) presents an intramolecular hydrogen bond that makes difficult the formation of more efficient interactions with PLA2 [78]. Free radicals have some roles in inflammation and systemic and local tissue injuries. Intrathecally administered edaravone, a free radical scavenger, had analgesic effects on inflammatory-induced acute and facilitated pain [79].

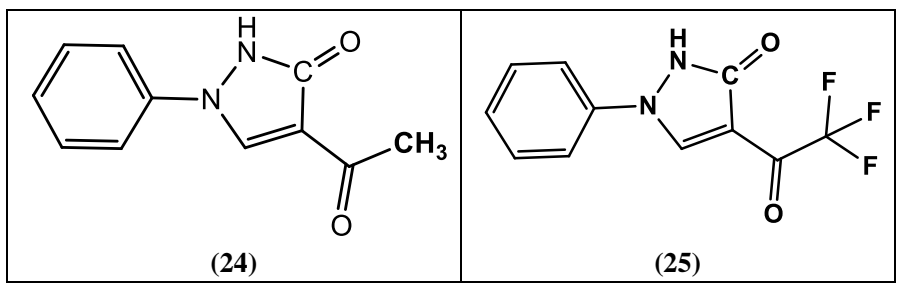

Oral dipyrone was showed more effective than an equal dose of aspirin or paracetamol in alleviating postoperative pain, and intravenous dipyrone $2.5 \mathrm{~g}$ was the same in efficacy to pethidine $50 \mathrm{mg}$. In patients with acute ureteral or biliary colic, dipyrone $2.5 \mathrm{~g}$ intravenously (i.v.) was similar in efficacy to indomethacin $50 \mathrm{mg}$ or pethidine $50 \mathrm{mg}$ [80]. pyrazolones exert analgesic effect by inhibiting prostaglandin (PG) synthesis. The early phase (1-2 h) inflammation is mainly mediated by histamine, serotonin, and increased synthesis of PGs in the damaged tissue surroundings. The late phase is sustained by PG release and mediated by bradykinin, leukotrienes, polymorph nuclear cells, and PGs produced by tissue macrophages. Fever results due to generation of mediators such as IL-1B, IL-6, interferons, and TNF-a cytokines higher the synthesis of PG which elevates the body temperature. From the results of the antipyretics study, pyrazolone derivatives produce the antipyretic action by inhibiting the PG synthesis by blocking cyclooxygenase (COX) isoenzymes, platelet thromboxane (TX) synthesis, and prostanoids synthesis $[81,82]$. There is increasing evidence that lysosomal enzymes play an important role in the development of acute and chronic inflammation [67]. Most anti-inflammatory drugs exert their beneficial effect by inhibiting either release of lysosomal enzymes or by stabilizing the lysosomal membrane which is one of the major events responsible for the inflammatory process.

Some pyrazolone derivatives were tested for their anti-inflammatory activity in-vitro using celecoxib as a reference drug. Compound $\mathbf{2 6}$ was found to be the most potent derivative of the series with $75 \%$ inhibition of inflammation. The pharmacological screening of these compounds was showed anti-inflammatory activity ranging from 16.66 to $75 \%$ inhibition after 3 hours, whereas the standard drug celecoxib was showed $83.33 \%$ inhibition after 3 hours. The compound 26 was found to be nearly equipotent to celecoxib. Compounds (27-29) shown this activity but less potent than compound $\mathbf{2 6}$ and celecoxib. The structural similarity of the celecoxib $(\log \mathrm{P}=3.90)$ and potent compound $26(\log \mathrm{P}=3.69)$ has the same pyrazole ring and methyl group $\left(\mathrm{CH}_{3}\right)$ is substituted by trifluoro methyl $\left(\mathrm{CF}_{3}\right)$. Compound 26 was showed maximum $\log \mathrm{P}$ value among all these compounds have maximum anti-inflammatory activity compared with celecoxib as COX-2 inhibitor [83].

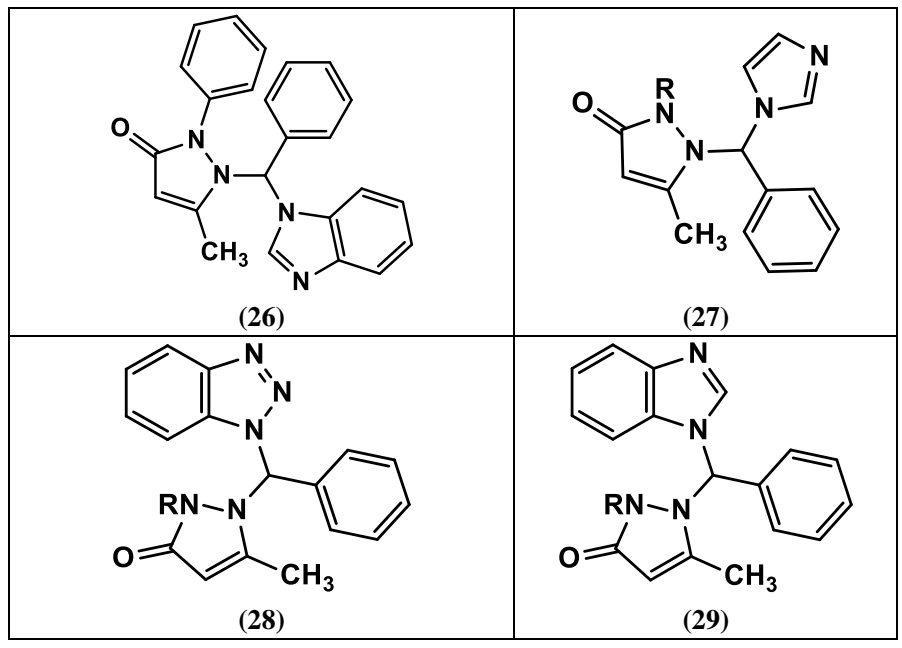

$\mathrm{R}=\mathrm{H},-\mathrm{C}_{6} \mathrm{H}_{5},-\mathrm{CONH}_{2}$,

\section{Anticonvulsant activity and Antidepressant activity}

Some 4,4-disubstituted pyrazolone compounds (30) were exhibited anticonvulsant activity [84]. For instance, Dipyrone was found to have anticonvulsant activity in three experimental epilepsy models. At a dose of 300 $\mathrm{mg} / \mathrm{kg}$ i.p., dipyrone blocked the maximal hind limb extension in the electroshock (MES) model in rats, the tonic-clonic component of acute soundinduced seizures and the limbic component of audiogenic kindling in genetically susceptible Wistar rats. In the MES model higher doses (400 and $500 \mathrm{mg} / \mathrm{kg}$ ) were also effective but lower doses (100 and $200 \mathrm{mg} / \mathrm{kg}$ ) were not [85].

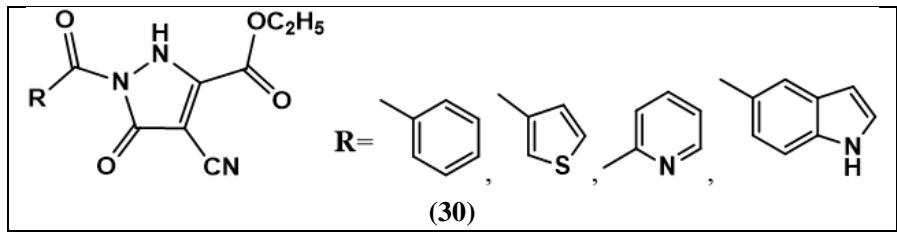

\section{Role of Pyrazolone in Cardiovascular Disease}

Edaravone enhances the expression of eNOS and restores the reduction in eNOS by oxidized low-density lipoprotein in endothelial cells. It shows it prevents cell damage induced by oxidative stress through not only direct ROS scavenging effect but also restoration of reduced eNOS expression [86]. A group of 3-phenyl or pyridyl-5-pyrazolone derivatives have been discovered which is useful in improving cardiac contractability. It is expected that edaravone has beneficial effects on coronary artery and myocardial cells after ischemic and postischemic myocardial injury in patients with ischemic heart diseases (IHDs), including acute myocardial infarction (MI) and angina pectoris [87,88].

The 3methyl-1-phenyl-2-pyrazolin-5-one derivative at a dose of $3 \mathrm{mg} / \mathrm{kg}$ attenuates the loss of myocardial creatine kinase activity from the left ventricular free wall in rats subjected to coronary artery occlusion for 10 minutes followed by reperfusion for 24 hours and reduced infarct size by approximately $50 \%$ compared with that in the control vehicle group [88, 89]. The 3-methyl-1-phenyl2-pyrazolin-5-one derivative attenuated the myocardial necrotic area by approximately $50 \%$ in isolated reperfusion rat heart subjected to coronary artery occlusion [86].

The effects of edaravone on left ventricular function and infarct size using a randomized, placebo-controlled, open-label protocol in 80 patients with acute MI. The i.v. use of edaravone at a dose of $30 \mathrm{mg}$ for 10 minutes before myocardial reperfusion reduced serum levels of creatine kinase-MB isoenzymes, a surrogate point of infarct size, and improved left ventricular ejection fraction in patients with acute MI compared with those in the placebo group [90,91] A series of 3-phenyl or pyridyl-5-pyrazolone derivatives $(\mathbf{3 1}, \mathbf{3 2})$ were useful in improving cardiac contractibility [21].

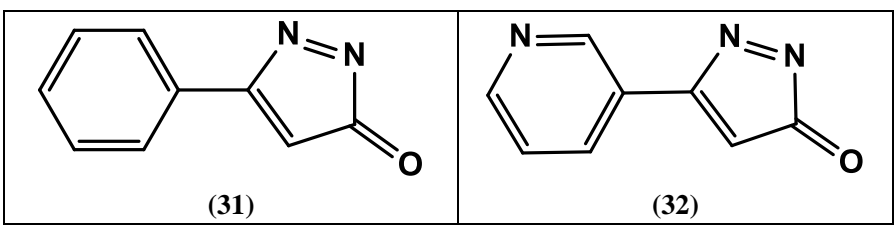

\section{Antithrombotic activity}

The beneficial effects of Edaravone on postischemic reperfusion injury $[92,93]$. It has been found to ameliorate infarct size and brain edema in embolization and transient focal, global, and hemispheric ischemia models in adult rats and to attenuate the hypoxic-ischemic encephalopathy in neonatal rats. In Japan, edaravone was approved in April 2001 for the treatment of acute brain infarction and subarachnoid hemorrhage in the acute phase. Several investigators have reported that edaravone has beneficial effects on the prevention of brain damage in patients with stroke [90]. Nafazatrom, a pyrazolone derivative has dual arachidonate enzyme inhibition. It exhibits antithrombotic and thrombolytic action by inhibiting 5-lipoxygenase catabolism of arachidonate. This drug reduces the myocardial infarct size after experimental coronary artery occlusion and reperfusion.

\section{Antiviral activity}

Pyrazolones are known to possess antiviral activity. The 4-iodo-1,5-dimethyl2-phenyl-pyrazol-3-one (iodoantipyrine) (33) was evaluated as antiviral agent against different varieties of viruses. 
These derivatives were showed potent antiviral activity against tick-borne encephalitis virus, hantavirus, $\mathrm{HBV}$ or $\mathrm{HCV}$, coxsackie A, and B enteroviruses, Rift valley fever viruses, and influenza type A viruses [94].

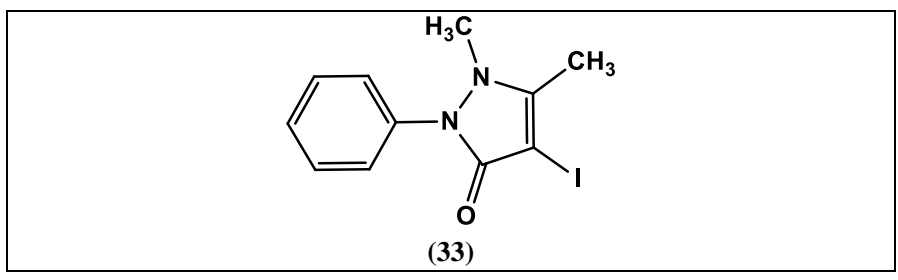

The antipyrine and related molecules can possess antiviral activity against a wide range of viruses. Iodoantipyrine or 4-iodo-1,5-dimethyl-2-phenyl-pyrazol3 -one is an iodinated form of antipyrine. The anti-inflammatory action of Iodoantipyrine produces several effects such as reduction of degranulation of the mast cells; suppression of PGs and arachidonic acid (AA) synthesis; membrane stabilizing activity; normalization of liver damage associated enzymes such as ALT and AST; the lower intensity of oxidation and phosphorylations. This derivative exhibited antiviral activity against a wide range of microbes including tick-borne encephalitis virus; hantavirus; influenza type A virus; herpesviruses; hepatitis B and C (HBV and HCV) viruses; Coxsackie A and B enteroviruses; papillomavirus; Venezuelan equine encephalomyelitis (VEE) virus; Rift Valley fever virus; poxviruses; and chlamydia. This compound was approved by Russia and neighboring countries for the prevention and treatment of tick-borne encephalitis (TBE), hemorrhagic fever with renal syndrome (HFRS), and seasonal flu [94].

\section{Neuroprotective effects}

Parkinson's disease is a neurological disorder described by the degeneration of nigrostriatal dopaminergic systems. In vitro study showed that edaravone appreciably ameliorated the survival of TH-positive neurons in a dose-responsive manner. Various apoptotic cells and HEt-positive cells considerably decreased, thus indicating that the neuroprotective effects of edaravone might be mediated by anti-apoptotic effects by the suppression of free radicals by edaravone. In vivo study exhibited that edaravone-used at 30 minutes after 6-OHDA (hydroxydopamine) lesion reduced the various amphetamine-induced rotations extensively than edaravone used at 24 hours [95].

\section{Hepatoprotective activity}

Fulminant hepatic failure is a serious disease that has a poor cure rate unless liver transplantation is performed. Edaravone has prevented Fas-induced acute liver failure in mice. Edaravone reduces various apoptotic hepatocytes and also prevents cytochrome c release and caspase 3 activities, accepted as markers of apoptosis after a mitochondrial disruption. Thus it protects hepatocytes from Fas-induced mitochondria-dependent apoptosis by regulating mitochondrial Bcl-xL and Bax [96]. The edaravone has a marked preventive effect on oxidative stress-induced acute liver injury. It also prevents endotoxin-induced liver injury after partial hepatectomy not only by attenuating oxidative damage but also by reducing the production of inflammatory cytokines, CINC, and iNOS, in part through the inhibition of NF-kB activation.

\section{Spasmolytic effect on smooth muscles}

Dipyrone showed a spasmolytic effect on the precontracted smooth muscle in vitro model. The premedication with dipyrone allowed the bronchoscope to pass through the bronchus more easily and increased the gas exchange in the lungs [97]. Dipyrone was also found to increase the gas exchange in the lungs when given as an analgesic for postoperative pain relief. The mechanism by which dipyrone relieves bronchospasm is not clearly understood. Although anti-inflammatory properties by way of COX enzyme and thus PG synthesis inhibition by NSAIDs is thought to be responsible for the spasmolytic effect of some NSAIDs, as dipyrone has no or minimal anti-inflammatory effect [98].

\section{SARS-Coronavirus 3C-Like protease inhibitors:}

A series of pyrazolone compounds (34) were tested by in vitro protease assay using fluorogenic substrate peptide. It was observed that several compounds showed potent inhibition against the 3C-Like protease and one of the inhibitors was also active against $3 \mathrm{C}$ protease [99].

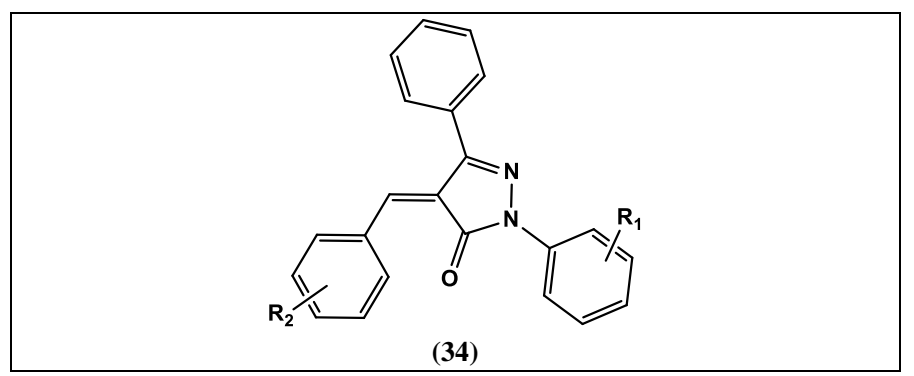

\section{Antihyperglycemic activity}

A group of 4-(arylmethyl and heteroarylmethyl)-5-substituted-3-pyrazolone derivatives (35a and 35b) were exhibited antihyperglycemic activity which is useful in non insulin-dependent diabeties mellitus [100,101]. The 1,2-dihydro4-[[4-(methylthio)phenyl]methyl]-5-(trifluoromethyl)-3H-pyrazol-3-one (36) in oral and subcutaneous glucose tolerance tests, indicated that unlike the renal and intestinal glucose absorption inhibitor phlorizin, it does not effectively block intestinal glucose absorption. Substitution of 4-methylthio, methylsulfinyl, or ethyl to a benzyl group at $\mathrm{C} 4$, in combination with trifluoromethyl at $\mathrm{C} 5$ of pyrazol-3-one, generated potent antihyperglycemic agents in obese, diabetic $\mathrm{db} / \mathrm{db}$ mice (16-30\% reduction in plasma glucose at $2 \mathrm{mg} / \mathrm{kg}$ ). The 5 -alkyl-4(arylmethyl)pyrazol-3-ones (hydroxyl tautomers) were exhibited potential oral antidiabetic effects, based on their ability to lower plasma glucose when used orally to obese, diabetic mice [102,103]. The ethyl 2-phenyl-1H-pyrazol-3-one4-carboxylate derivatives (38) were tested for their hypoglycemic activity. These compounds were exhibited potent hypoglycemic activity[102]. The 4-(arylmethyl and heteroarylmethyl)-5-subsituted-3-pyrazolone derivatives (39) were also tested for its antihyperglycaemic activity and showed significant antihyperglycaemic activity which is useful in non insulin-dependent diabetes mellitus (NIDDM) [104].

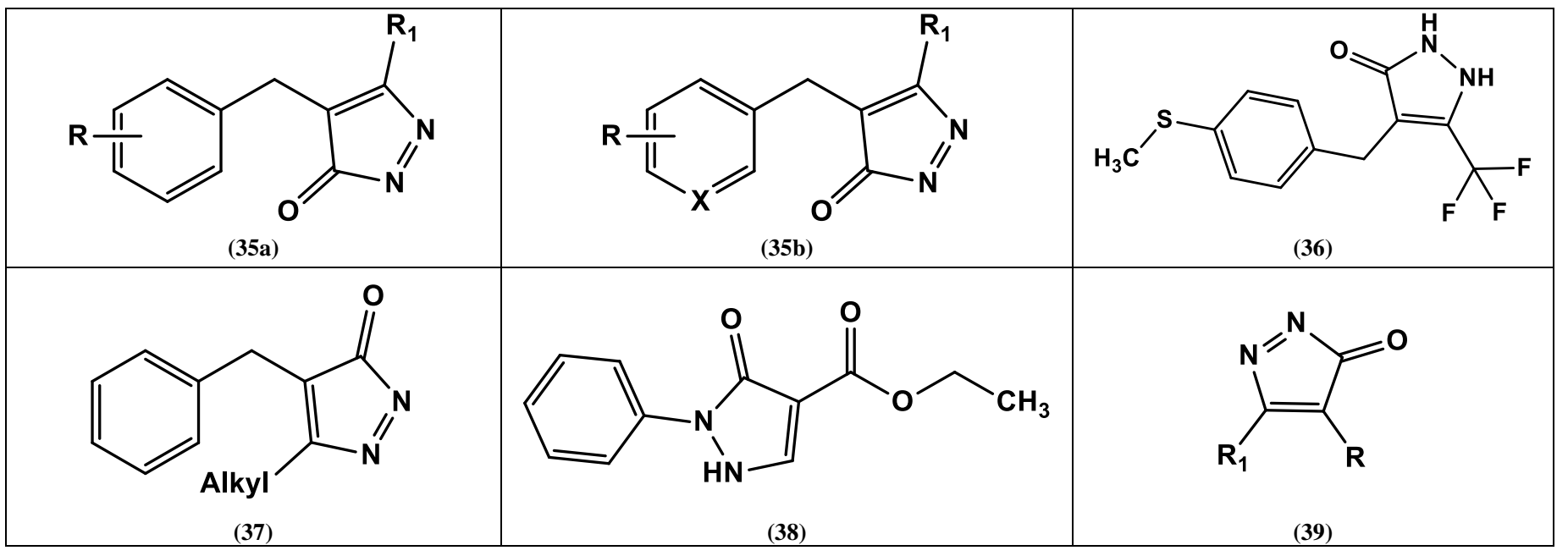

$\mathrm{R}=$ aryl/heteroaryl rings $\mathrm{R}^{\prime}=$ substituted groups 


\section{Radioprotective effect}

Analgin, antipyrine, and aminopyrine, if administered to mice in large doses $3 \mathrm{~h}$ before irradiation $(800 \mathrm{R})$, increases the survival rate and prolong the life of the dying animals. In combination with cystamine, these compounds increase the chances of survival of the mice after the period of acute intestinal death following irradiation in a dose of $1050 \mathrm{R}$. the pyrazolone derivatives considerably increase the resistance to hypoxia of both healthy mice and irradiated mice at various periods of acute radiation sickness [105].

\section{Toxicity and adverse effects}

The most frequently reported side effects of the pyrazolone derivatives are skin rashes. Gastrointestinal side effects are rare. Blood dyscrasias, mostly associated with aminopyrine (Brogden. 1986). Side effects, including acute renal failure, liver dysfunction, acute allergic reaction, disseminated intravascular coagulation, leukocytopenia, thrombocytopenia, and renal dysfunction. Edaravone should be carefully used in elderly patients and patients with renal disease, liver disease, hematologic disease, or dehydration. Therapeutic uses of phenylbutazone are limited because it possesses toxic side effects which include peptic ulcer with hemorrhage, hypersensitivity reactions of the serum sickness type, nephritis, hepatitis, aplastic anemia, agranulocytosis, leucopenia, and thrombocytopenia [77]. Hence it is necessary to modify the structure of pyrazolones to minimize the side effect and to improve its therapeutic application.

\section{Synthesis approaches of pyrazolone derivatives}

Advancement in the synthesis or derivatization of pyrazolones and exploration of their applications have been emerged and grown exponentially. Here we describe the various reported strategies for chemical synthesis of pyrazolone derivatives. A light was also put on their various bio-activities. This work will help to recognize the site of modification on the pyrazolone skeleton, to design the synthetic strategy and to explore their possible bio-application $[106,107]$.

Synthesized various substitutions on $N, N$-dialkylamino alkyl-substituted bisindolyl, and diphenyl pyrazolone derivatives (40a-f) using ethyl ester, acyl chloride and hydrazines (Scheme 1). The growth inhibitory activity evaluation in human cell lines (HT-29, HeLa, and PC-3) indicated compound 40b and 40e as most potent with $\mathrm{IC}_{50} 11.3$ and $46.7 \mu \mathrm{m}$, respectively [108].

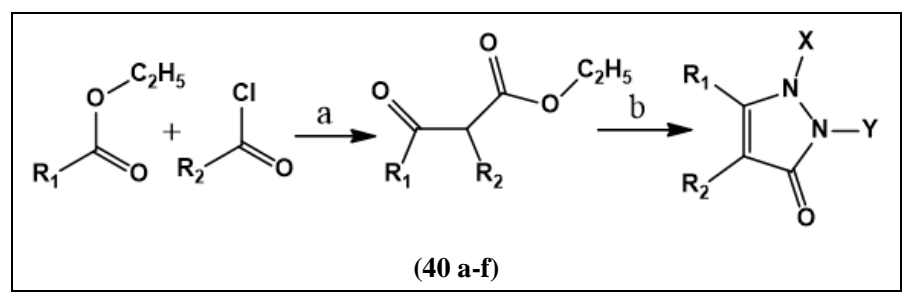

Scheme 1. Synthesis of bis arylpyrazolones (40a-f): (a) BuLi/THF, DIPA, $-78^{\circ} \mathrm{C} ;(\mathrm{b})$.

\begin{tabular}{|c|c|c|c|c|}
\hline compound & R1 & R2 & X & Y \\
\hline 40a & $\mathrm{Ph}$ & $\mathrm{Ph}$ & $\mathrm{H}$ & $\mathrm{H}$ \\
\hline 40b & $N$-Methylindolyl & $N$-Methylindolyl & $\mathrm{H}$ & $\mathrm{H}$ \\
\hline 40c & $\mathrm{Ph}$ & $\mathrm{Ph}$ & $\mathrm{H}$ & $\left(\mathrm{CH}_{2}\right)_{2} \mathrm{~N}(\mathrm{Me})_{2}$ \\
\hline 40d & $\mathrm{Ph}$ & $\mathrm{Ph}$ & $\mathrm{H}$ & $\left(\mathrm{CH}_{2}\right)_{2} \mathrm{~N}(\mathrm{Et})_{2}$ \\
\hline 40e & $N$-Methylindolyl & $N$-Methylindolyl & $\mathrm{H}$ & $\left(\mathrm{CH}_{2}\right)_{2} \mathrm{~N}(\mathrm{Et})_{2}$ \\
\hline 40f & $\mathrm{Ph}$ & $\mathrm{Ph}$ & $\left(\mathrm{CH}_{2}\right)_{2} \mathrm{~N}(\mathrm{Et})_{2}$ & $\mathrm{H}$ \\
\hline
\end{tabular}

Synthesized phenyl pyrazolones and converted them into a series of corresponding pyrazole derivatives (41a-g and 42a-e) using the Buchi Syncore synthesizer (Scheme 2) [109]. Their biological evaluation and SAR indicated that small lipophilic substituents in pyrazole ring $\left(\mathrm{R}_{1}\right)$ and phenyl ring $\left(\mathrm{R}_{2}\right)$ and potentiate the activity as inhibitors of $M$. tuberculosis. The presence of $p$-chlorobenzoyl functionality was found to be essential for the antitubercular (anti-TB) activity of the compounds.

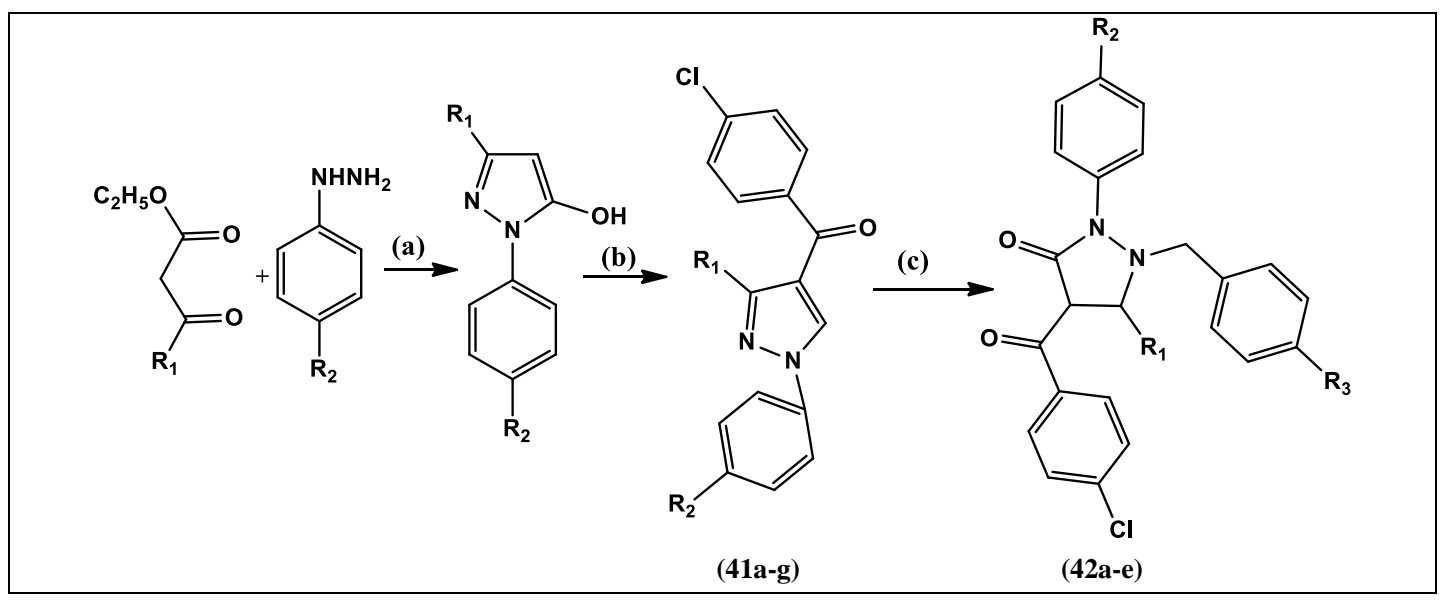

Scheme 2. Synthesis of pyrazolones to pyrazoles: (a) Polymer bound $p$-toluenesulfonic acid, EtOH, Buchi Syncore, 300 rpm (b) p-Cl-benzoyl chloride, $\mathrm{Ca}(\mathrm{OH})_{2}$, dioxane, Syncore, 300 rpm, reflux (c) Benzyl halide, NaH, DMF, NaI, Syncore, 300 rpm.

Table 1. The anti-TB activity of benzoyl pyrazoles (41a-g) and benzoyl pyrazolones (42a-e) against M. tuberculosis.

\begin{tabular}{|c|c|c|c|c|c|c|c|}
\hline Compd & $\mathbf{R}_{1}$ & $\mathbf{R}_{2}$ & $\mathbf{M I C}(\mu \mathrm{g}$ mL-1) & Compd & $\mathbf{R}_{1}$ & $\mathbf{R}_{2}$ & $\mathbf{M I C}(\mu \mathrm{g} \mathrm{mL}-1)$ \\
\hline 41a & $\mathrm{CH}_{3}$ & $\mathrm{Cl}$ & 6.25 & $42 a$ & $\mathrm{Bn}$ & $\mathrm{Cl}$ & 16 \\
\hline $41 \mathrm{~b}$ & $\mathrm{CH}_{3}$ & $\mathrm{H}$ & 6.25 & $42 b$ & $(p-\mathrm{F}) \mathrm{Bn}$ & $\mathrm{H}$ & 32 \\
\hline $41 \mathrm{c}$ & $\mathrm{CH}_{3}$ & $\mathrm{~F}$ & 12.5 & $42 c$ & $\left(p-\mathrm{NO}_{2}\right) \mathrm{Bn}$ & $\mathrm{H}$ & $>32$ \\
\hline 41d & $\mathrm{C}_{6} \mathrm{H}_{5}$ & $\mathrm{Cl}$ & 16 & 42d & $\mathrm{Bn}$ & $\mathrm{H}$ & $>64$ \\
\hline $41 \mathrm{e}$ & $\mathrm{CH}_{3}$ & $\mathrm{Br}$ & 4 & $42 \mathrm{e}$ & $\left(p-\mathrm{NO}_{2}\right) \mathrm{Bn}$ & $\mathrm{Cl}$ & 32 \\
\hline $41 f$ & $\mathrm{CH}_{3}$ & $\mathrm{CH} 3$ & 16 & & & & \\
\hline 41g & $\mathrm{CH}_{3}$ & Isopropyl & 16 & & & & \\
\hline
\end{tabular}

Synthesis of combretastatin-fused-pyrazolones using a multistep strategy (Scheme 3) and tested for their cytotoxicity and anti-tubulin activity. Compounds $\mathbf{4 3 a - 7}$ were found to be most potent among all tested compounds (Table-2). However, only compound $\mathbf{4 4 a - 7}$ showed tubulin polymerization inhibitory activity $98 \%$ $[110,111]$. 


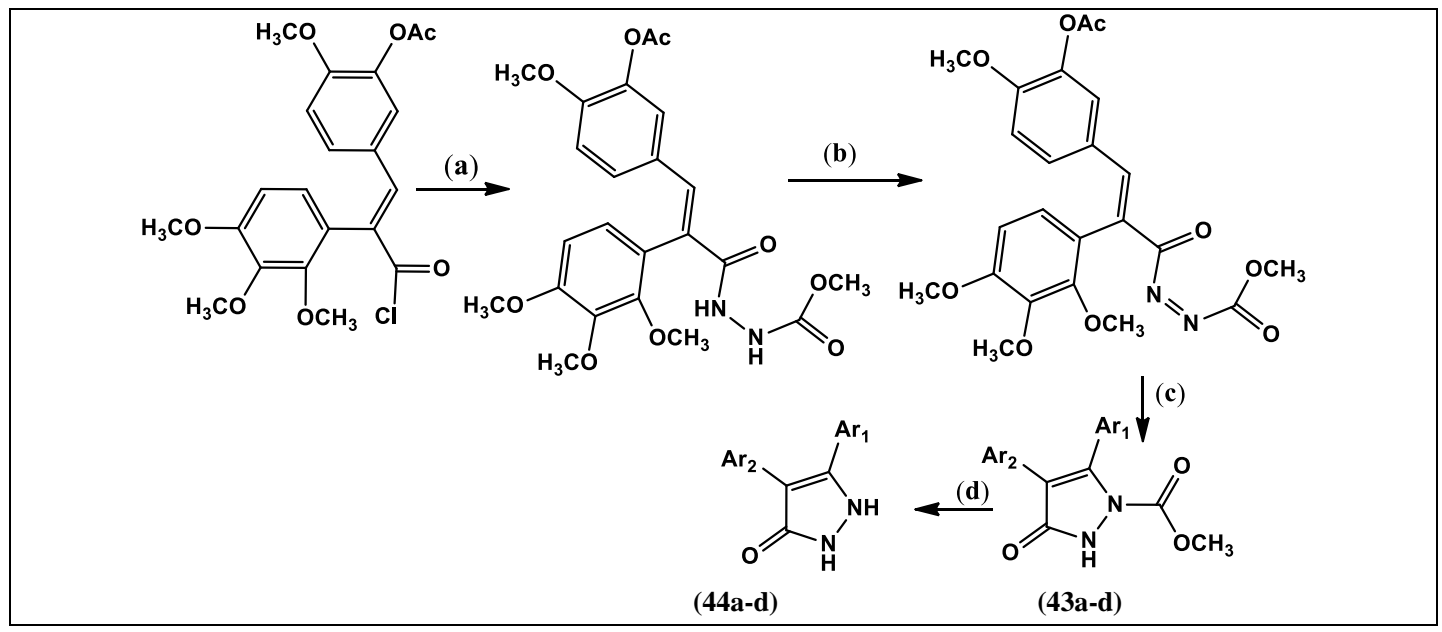

Scheme 3. Synthesis of combretastatin-fused-pyrazolones: (a). $\mathrm{NH}_{2} \mathrm{NHCOCH}_{3}, \mathrm{Py}, \mathrm{DCM}, 0^{\circ} \mathrm{C}-\mathrm{rt}, 17 \mathrm{~h}$; (b). $\mathrm{NBS}, \mathrm{Py}, \mathrm{rt}, 10 \mathrm{~min}$; (c). DCM, reflux, 4h; (d). NaOH/MeOH, $\mathrm{DCM} / \mathrm{MeOH}, \mathrm{rt}, 31 \mathrm{~h}$ and $\mathrm{HCl}$.

Table 2. Cytotoxicity profile of combretastatin-fused-pyrazolones (43a-d and 44a-d).

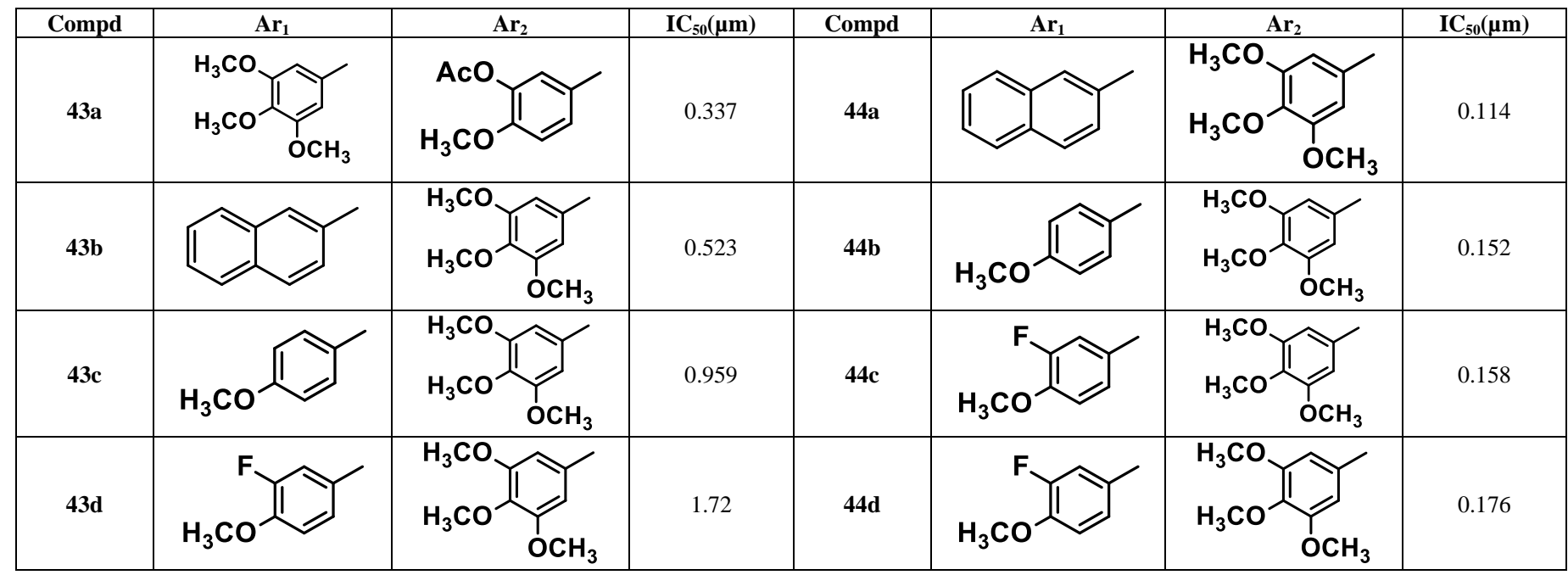

The $\mathrm{Ce} / \mathrm{SiO}_{2}$ catalyzed synthesis of $\mathrm{N}$-arylpyrazolone skeleton (45) using a multicomponent one-pot synthetic strategy under aqueous media with a yield of $83-92 \%$ (Scheme 4). These pyrazolones were exhibited promising antimicrobial activity against both bacteria and fungi [112].

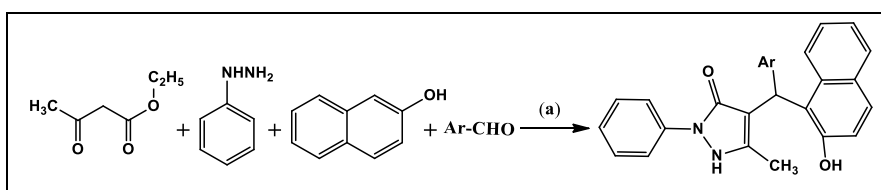

(45)

Scheme 4. Multicomponent synthesis of $\mathrm{N}$-arylpyrazolones (8): (a) $\mathrm{Ce} / \mathrm{SiO}_{2}$, $\mathrm{H}_{2} \mathrm{O}$, D.

Recently, synthesized the $N$-arylfluoropyrazolones (46) using quinine catalyzed asymmetric fluorination with yield up to $98 \%$ (35-81\% ee), Scheme 5 [113].

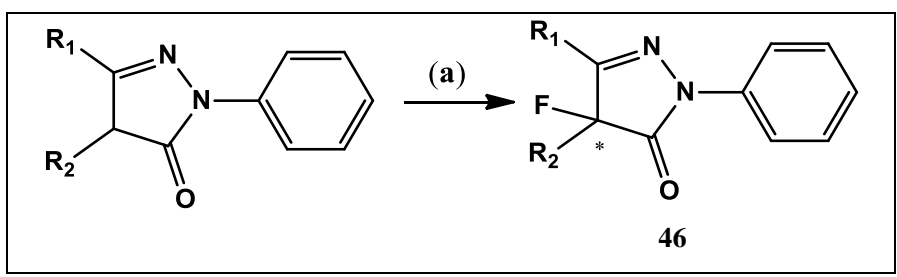

Scheme 5. Synthesis of $N$-arylfluoropyrazolones (9): (a) $N$-FBS, Quinine, $\mathrm{Cs}_{2} \mathrm{CO}_{3}, \mathrm{H}_{2} \mathrm{O}, \mathrm{CHCl}_{3},-60{ }^{\circ} \mathrm{C}$.
Synthesis of bis pyrazolones (47 and $\mathbf{4 8}$ ) from hydrazide derivatives of pyrazolone using acid-catalyzed condensation-cyclization reaction under reflux conditions (Scheme 6) [114]. These bis pyrazolones have been shown comparable antibacterial (against $S$. aureus, B. cereus, E. coli, and $P$. aeruginosa) and antifungal (against $A$. niger, $C$. albicans) activities.

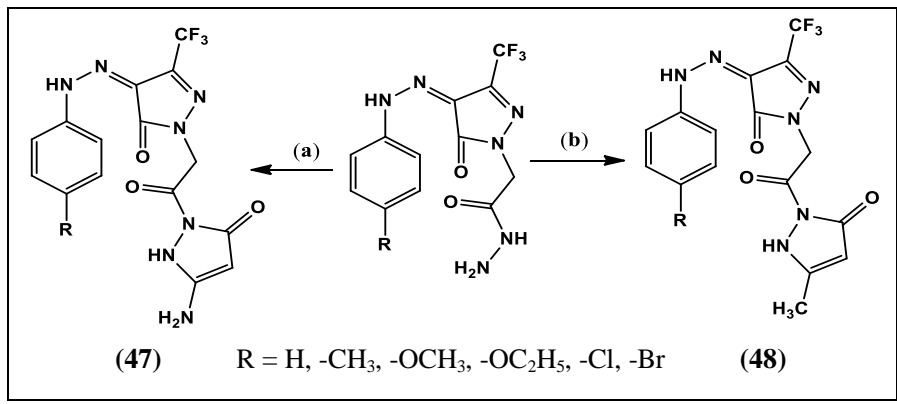

Scheme 6. Synthesis of 3-amino and 3-methyl bis pyrazolones $(47,48)$ : (a) $\mathrm{CH}_{3} \mathrm{COCH}_{2} \mathrm{COOC}_{2} \mathrm{H}_{5}, \mathrm{AcOH}, \mathrm{EtOH}$; (b) $\mathrm{CNCH}_{2} \mathrm{COOC}_{2} \mathrm{H}_{5}, \mathrm{AcOH}$, EtOH.

Sphingosine 1-phosphate receptor 1 (S1P1) is recognized to involve in the pathogenesis of inflammation-related diseases of immune, vascular, and nervous systems [115]. The S1P1 antagonists are expected to be potential therapeutic 
agents for cardiovascular disorders and angiogenesis. In a molecular library screening study, S1P1 receptor antagonizing pyrazolone derivative 49 inhibits S1P1 receptors with IC50 $17.0 \mathrm{mM}$ [116]. Compound 49 led to the identification of novel biphenyl sulfonates as S1P1 receptor antagonists.

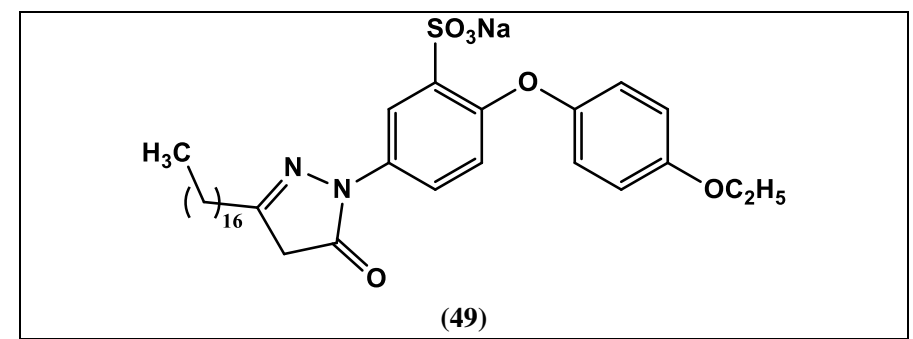

Lavergne et al. synthesized the $N$-alkylated pyrazolones (50) from enol ethers and hydrazones by aminocarbonylation with a yield of 45-95\% (Scheme 7) [117].<smiles>[R2]C=C([R]Oc1ccccc1)O[R6]</smiles>

$\mathrm{X}=$ Fluorenyl, benzyl,

$\mathrm{R}_{2}, \mathrm{R}_{3}=\mathrm{H}, \mathrm{H} ; \mathrm{C}_{2} \mathrm{H}_{5}, \mathrm{H} ; \mathrm{H}, \mathrm{Me} ; \mathrm{H},-\mathrm{CH}_{2} \mathrm{CH}_{2} \mathrm{OH}$; 2,4-dimethylpentanyl

$\mathrm{H},-\mathrm{CH}_{2} \mathrm{CH}_{2} \mathrm{CH}_{2} \mathrm{OH}$
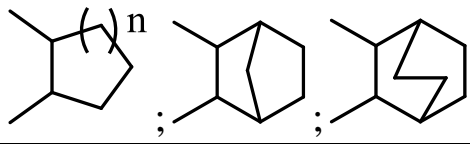

Scheme 7. Synthesis of $N$-alkylated pyrazolones: (a) $\mathrm{Et}_{3} \mathrm{~N}, \mathrm{PhCF}_{3}(0.1 \mathrm{M})$, 70-100 ${ }^{\circ} \mathrm{C}$ (sealed vial); (b) $\mathrm{NaBH}_{4}, \mathrm{MeOH},-20{ }^{\circ} \mathrm{C}$ to rt, then $\mathrm{NH}_{4} \mathrm{Cl}$ or $\mathrm{NH}_{4} \mathrm{Cl}$, $p$-TsOH, $\mathrm{CHCl}_{3}, 60{ }^{\circ} \mathrm{C}, 3 \mathrm{~h}$

Recently, one pot synthesis of highly strained chiral spiropyrazolones (51) using $\mathrm{Br}_{2}$ assisted cyclization with yield of 61-97\% (Scheme 8) [118] and known for their antimicrobial [119], antitumor [120], and anti-trypanosomiatic activities [121].

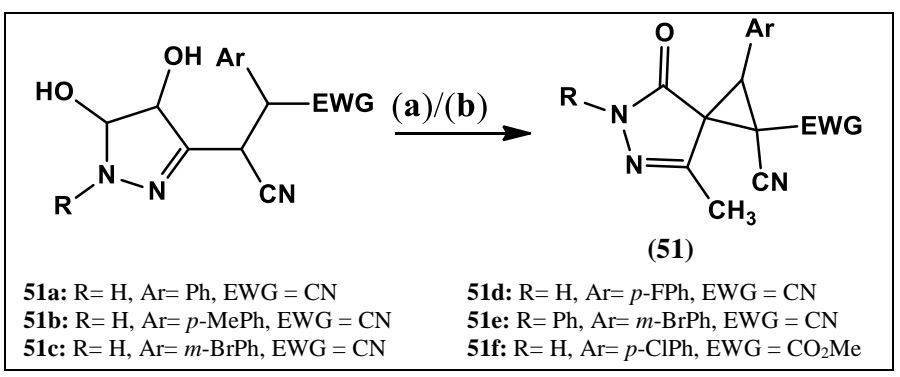

Scheme 8. Synthesis of spiropyrazolones: (a) $\mathrm{Br}_{2}$, EtONa, EtOH, r.t., 3h; (b) $0.2 \mathrm{M} \mathrm{Br}_{2}$ in water, EtOH, $40{ }^{\circ} \mathrm{C}, 1 \mathrm{~h}$.

A asymmetric synthesis of spiropyrazolones (52a-d) from benzylidenepyrazolones and glutaraldehyde using (S)-2-(diphenyl ((trimethylsilyl)oxy)methyl)pyrroline as a catalyst (Scheme 9) [122]. Final products obtained with excellent yields and diastereoselectivities but poor enantioselectivities (Table 4.)

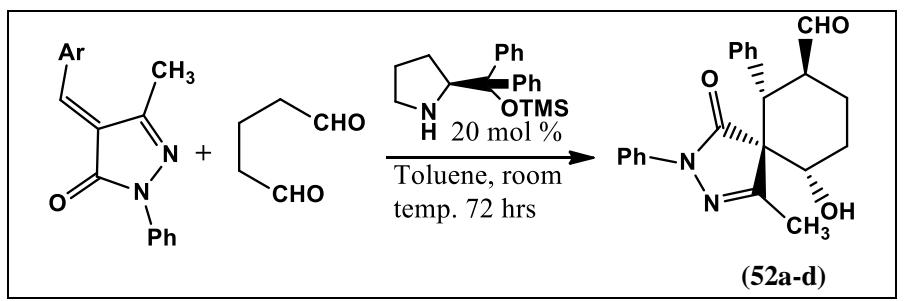

Scheme 9. Synthesis of spiropyrazolones (52a-d).
Table 4. Diastereoselectivity and yield of spiropyrazolones (52a-d).

\begin{tabular}{|c|c|c|c|}
\hline Compd & Ar & Diastereoselectivity (d.r.) & \% Yield \\
\hline 52a & $\mathrm{Ph}$ & $>8: 1$ & 72 \\
\hline 52b & $(p-\mathrm{Br}) \mathrm{Ph}$ & $>8: 1$ & 87 \\
\hline 52c & $(p-\mathrm{Me}) \mathrm{Ph}$ & $11: 1$ & 93 \\
\hline 52d & $(o-\mathrm{Cl}) \mathrm{Ph}$ & $14: 1$ & 92 \\
\hline
\end{tabular}

Oxindole containing spiropyrazolones (53) through DIPEA or squaramide catalyzed diastereoselective Michael/alkylation cascade reactions of arylidenepyrazolones with 3-chlorooxindoles (Scheme 10) [123].

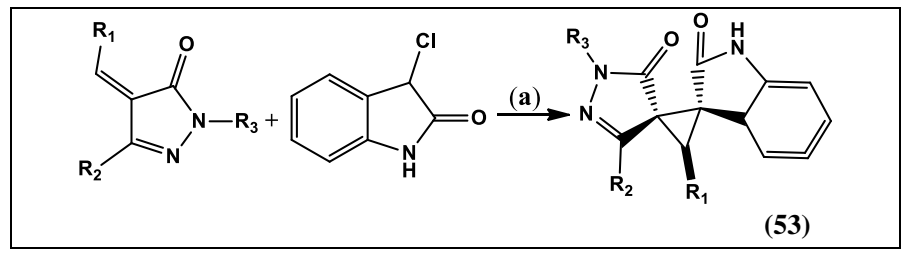

Scheme 10. Synthesis of oxindole containing spiropyrazolones: (a) DIPEA (100 $\mathrm{mol} \%$ ), $\mathrm{CH}_{2} \mathrm{Cl}_{2}$, r.t. $12-36 \mathrm{~h}$ or squaramide (5 mol $\left.\%\right), \mathrm{K}_{2} \mathrm{CO}_{3}(100 \mathrm{~mol} \%), \mathrm{CH}_{3} \mathrm{CN}$.

The synthesized arylidene pyrazolones (54) and C-tethered bispyrazol-5-ols (55) from acetylene dicarboxylates, phenylhydrazine, and aryl aldehydes using multicomponent domino reactions with yield 75-92\% (Scheme 11) [124].

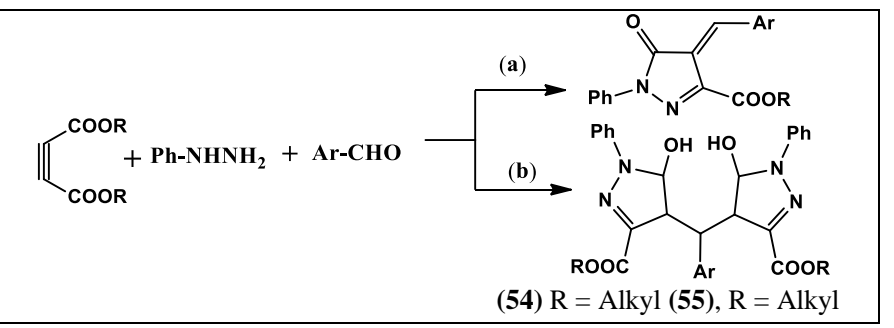

Scheme 11. Synthesis of bispyrazolone and bispyrazol-5-ol: (a) and (b) $\mathrm{CH}_{3} \mathrm{COOH}$, MW or rt, $10 \mathrm{~min}$.

The synthesis of $\mathrm{N}$-aryl 4-aryledine pyrazolones (56) from phenyl hydrazine, 4-pyrazolaldehyde and $N$-arylpyrazolone via Knovenagel condensation (Scheme 12) [125]. The compounds were were active against Gram-positive (B. subtilis and S. aureus), Gram-negative (P. fluorescens and E. coli) bacteria, and pathogenic fungi (C. albicans and S. cerevisiae) with MIC 0.4-400 mg/ml.

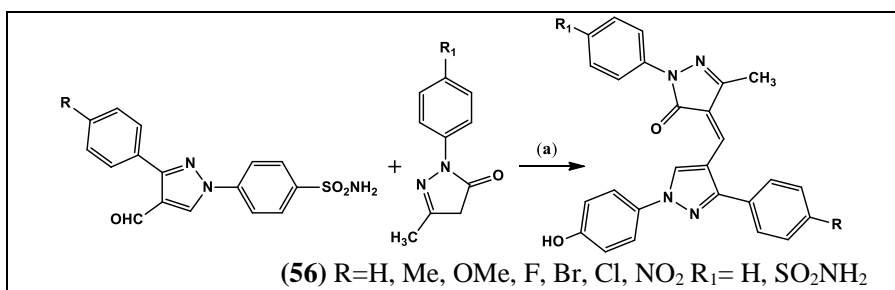

Scheme 12. Synthesis of $N$-aryl 4-aryledine pyrazolones: (a) $\mathrm{Et}_{3} \mathrm{~N}, \mathrm{EtOH}$, reflux.

Halogenated pyrazolones are useful synthetic intermediates for the synthesis of dyes [126] fused- and spiro-heterocyclic compounds [127, 128]. Brominated pyrazolones were synthesized using $\mathrm{Br}_{2}$ acetic acid, $\mathrm{Br}_{2}$-water and $\mathrm{N}$-bromosuccinimide (NBS) [129-131]. Synthesized di-bromopyrazolones (57) using pyrazolone or hydroxypyrazolones and $N$-bromobenzamide with product yield 90\% (Scheme 3) [132].

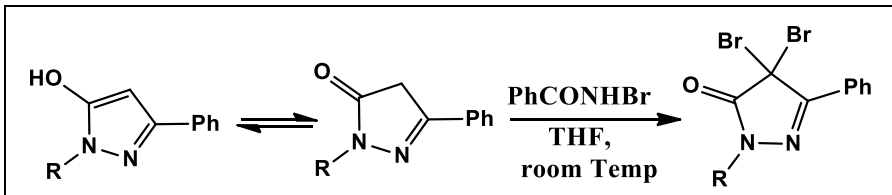

(57) $\mathrm{R}=\mathrm{H}, \mathrm{Ph}$, Pyridyl, Isoquinolinyl, etc.

Scheme 13. Synthesis of dibromopyrazolones (57). 
A green method for synthesis of $N$-arylpyrazolones (58) using CuI nanoparticles catalyzed four-component reaction under sonication (Scheme 14). Under optimized reaction conditions, the yield of product was found to be $86-93 \%$ [133].

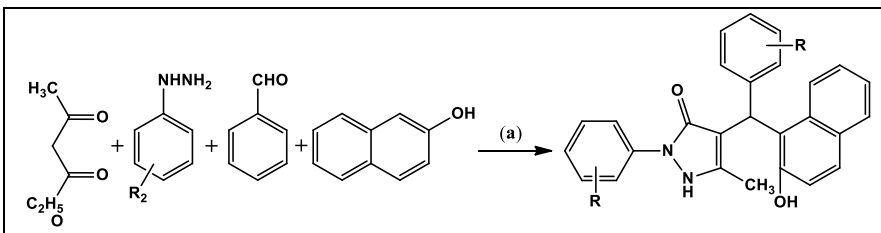

(58) $\mathrm{R}_{1}=\mathrm{H}, o-\mathrm{Cl}, o-\mathrm{Me}, o-\mathrm{NO}_{2}, p-\mathrm{Cl}, p-\mathrm{Br}, p-\mathrm{Me}, p-\mathrm{NO}_{2} \mathrm{R}_{2}=\mathrm{H}, p-\mathrm{Cl}$

Scheme 14. Four-component synthesis of pyrazolones: (a) $\mathrm{EtOH} / \mathrm{H}_{2} \mathrm{O}$, ultrasound irradiation, rt, 35-40 min.

Enantioselective synthesis of $p$-benzoquinone substituted pyrazolones (59) using cinchona alkaloid, quinine, catalyzed Michael addition/oxidation reaction with a yield up to $72 \%$ (99\% ee), Scheme 15 [134].<smiles>[R]C1=NN(c2ccccc2)C(=O)C1[R]</smiles>

$\mathbf{R}_{\mathbf{1}}=\mathrm{Me}, \mathrm{Ph}, \mathrm{p}-\mathrm{BrPh}, \mathrm{p}-\mathrm{MePh}$ 2-Naphthyl, 2-Thienyl
Scheme 15. Synthesis of benzoquinone substituted pyrazolones: (a) Quinine (2 mol \%), DCE, $25^{\circ} \mathrm{C}, 24 \mathrm{~h}$.

Synthesis of fused-ring pyrazolones (60) from ethyl 2-oxocyclohex-3enecarboxylate and hydrazine hydrate in the presence of a base with yield 70-78\% (Scheme-16) [135]. These compounds were exhibited good antimicrobial activity against $B$. subtilis and $C$. albicans with MIC values of $0.313-1.25 \mu \mathrm{g} / \mathrm{ml}$. The compounds with $p$-OH group were exhibited good antioxidants and iron metal chelating properties.<smiles>CCOC(=O)C1C(=O)C=C(c2ccccc2)CC1c1cccc([Hg]c2ccccc2)c1</smiles>

Scheme 16. Synthesis of fused-ring pyrazolone; (a) $\mathrm{NH}_{2} \mathrm{NH}_{2} \cdot \mathrm{H}_{2} \mathrm{O}$, Base

Pyrazolone derivatives (61 and 62) have therapeutic potential in amyotrophic lateral sclerosis (ALS) through activation of proteasome pathway [136]. On biological evaluation, compound $\mathbf{6 2}$ was found to be highly potent against ALS with $\mathrm{EC}_{50} 0.07 \mathrm{mM}$.

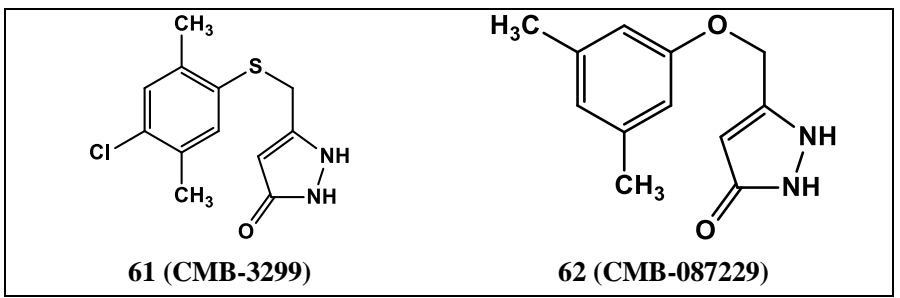

Figure 3. Structures of Anti-ALS pyrazolones.
Synthesized the substituted pyrazolo-triazinylidene fused ring adduct of 1-(phenyl(piperidin-1-yl)methyl)urea/thiourea (Scheme-17) [137]. Both compounds (63a and 63b) have been shown synergistic effect on CNS depression with diazepam at a dose of $0.5 \mathrm{mg} / \mathrm{kg}$.

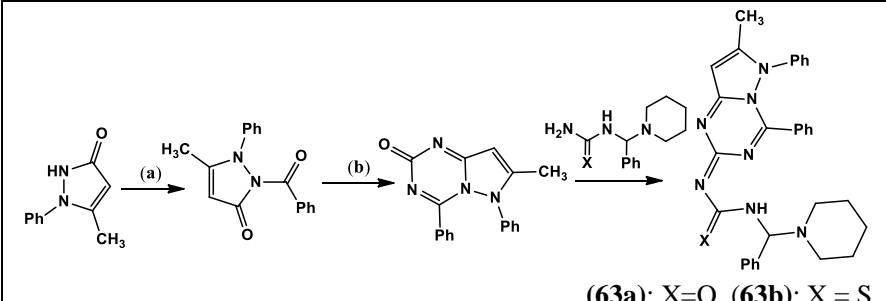

Scheme 17. Synthesis of pyrazolo-triazinylidene derivatives.

Synthesis of chiral 4-aminopyrazolones (64) from corresponding pyrazolones and azodicarboxylates using $N, N^{\prime}$-dioxide gadolinium(III) complex ( $\mathrm{L}$-Gd( $\left.(\mathrm{OTf})_{3}\right)$ catalyzed asymmetric $\alpha$-amination (Scheme-18) [138]
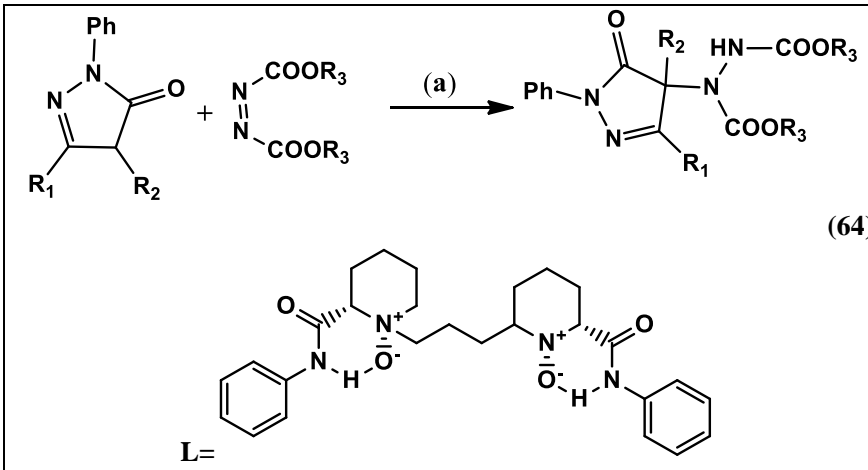

Scheme 18. Asymmetric synthesis of 4-aminopyrazolones (64): (a) L-Gd(OTf $)_{3}$ (0.05 or $1 \mathrm{~mol} \%), 4 \AA \mathrm{MS}, \mathrm{DCM},-20^{\circ} \mathrm{C}$.

Pyrazolone derivative $(\mathbf{6 5})$ as selective and highly potent orally active $c$-Met inhibitors, the receptor tyrosine kinase, $c$-Met, is known as a vital target for anticancer agents. Compound $\mathbf{6 5}$ (AMG458) was showed the most favorable $c$-Met based anticancer profile among the tested compounds. Synthesis of $\mathbf{6 5}$ was done by coupling of 4-quinolinyloxy-2-pyridinamine moiety with a pyrazolone nucleus (Scheme-19) [139].

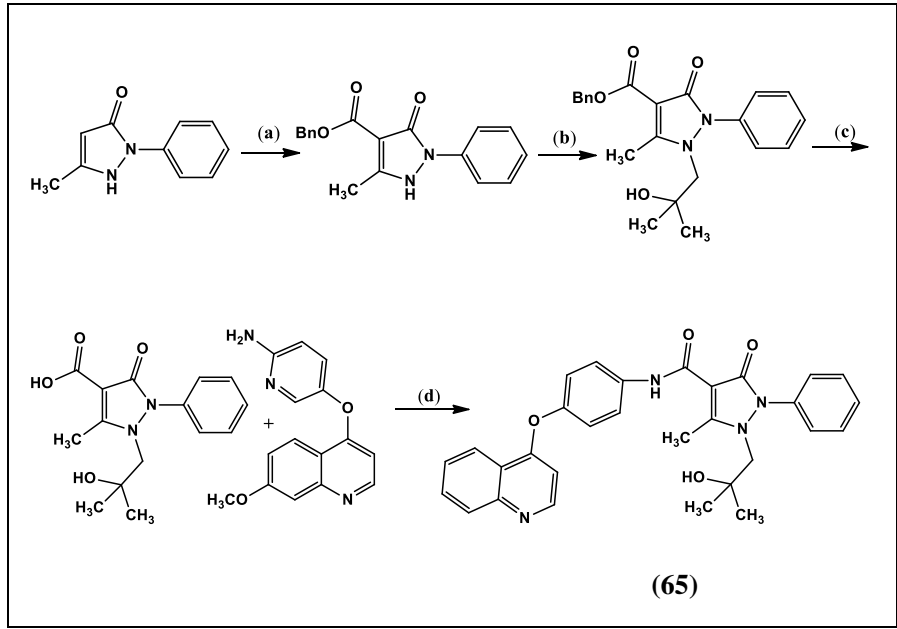

Scheme 19. Synthesis of AMG458: (a) $\mathrm{BnCOCl}, \mathrm{Ca}(\mathrm{OH})_{2}$, dioxane (b) 1,1-dimethyloxirane, AlMe3, chlorobenzene (c) $\mathrm{H}_{2}, \mathrm{Pd} / \mathrm{C}, \mathrm{MeOH}$ (d) HATU, $(i \operatorname{Pr})_{2} \mathrm{EtN}, \mathrm{DMF}, 60^{\circ} \mathrm{C}$.

Two step synthesis of spiropyrazolones (66) from 3-benzoyl-1phenylpiperidin-2-ones using iodine-mediated oxidative $\mathrm{C}-\mathrm{N}$ bond formation with a yield of 47-93\% (Scheme-20) [50]. 


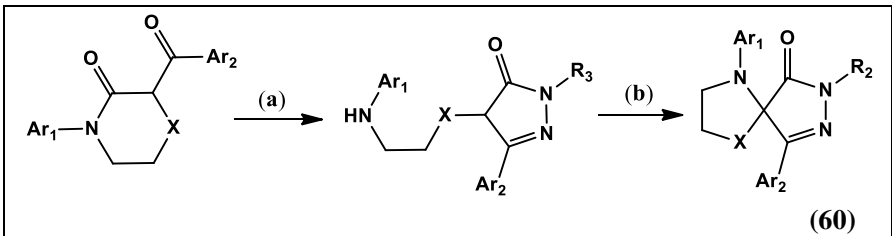

(60)

$\mathbf{X}=\mathrm{C}, \mathrm{O} ; \quad \mathbf{A r}_{1}=\mathrm{Ph}, o / m / p-\mathrm{MePh}, p-\mathrm{MeOPh}, p-\mathrm{ClPh}, p-\mathrm{CF}_{3} \mathrm{Ph}, p-\mathrm{CNPh} ;$ $\mathbf{A r}_{2}=\mathrm{Et}$, o-MePh, m-BrPh, p-CNPh, p-MeOPh,2-thienyl, 4-pyridyl; $\mathbf{R}_{\mathbf{3}}=\mathrm{H}, \mathrm{Ph}$, $\mathrm{Bn}$

Scheme 20. Synthesis of spiropyrazolones (66): (a) $\mathrm{R}_{3} \mathrm{NHNH}_{2} \cdot \mathrm{H}_{2} \mathrm{O} / \mathrm{HCl} / 2 \mathrm{HCl}$, EtOH, 75-90 ${ }^{\circ} \mathrm{C}$, overnight (b) I2, AgOTf, $0{ }^{\circ} \mathrm{C}$, Stirring, 30-60 min.

Asymmetric synthesis of pyrrolidine-2-thione-spiropyrazolones (67) from benzylidene pyrazolones via an organocatalytic Michael/cyclization sequence (Scheme-21). The reaction afforded spiropyrazolones containing three contiguous stereogenic centers with high levels of diastereo- and enantioselectivity (up to 20:1 dr and $99 \%$ ee) [141].

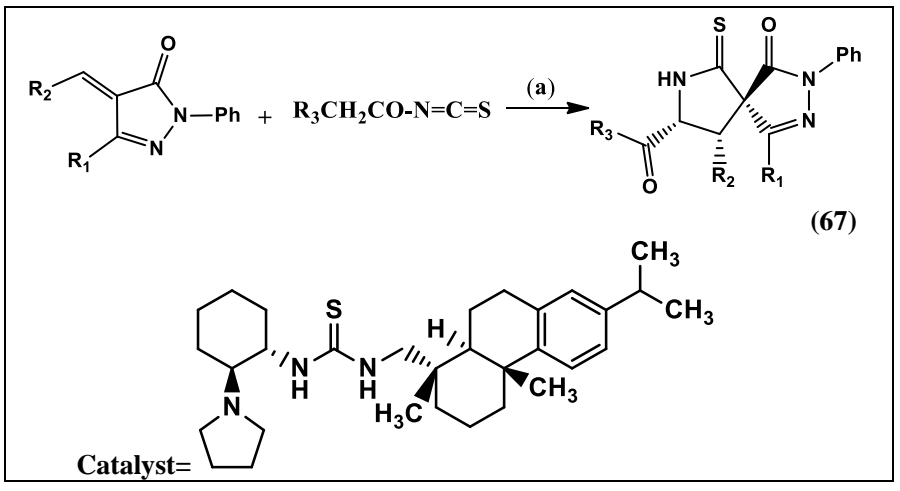

Scheme 21. Synthesis of pyrrolidine-2-thione-spiropyrazolones (67): (a) Cat. (15 mol \%), DCM, r.t.

Dialkoxybenzylidene pyrazolones (68) as potent HIV-1 integrase inhibitors (Scheme-22), the structure-activity relationship (SAR) indicated that compounds with substituents $\mathrm{R}_{1}=3$,5-dichlorophenyl substituent $\left(\mathrm{IC}_{50}=12 \pm 1 \mathrm{mM}\right), \mathrm{R}_{2}=3$ (4-fluorobenzyl)4-methoxy benzylidene $\left(\mathrm{IC}_{50}=11 \pm 1 \mathrm{mM}\right)$ and $\mathrm{R}_{3}=$ carboxylate $\left(\mathrm{IC}_{50}=19 \pm 3 \mathrm{mM}\right)$ having higher potency than other in strand transfer assay [142].

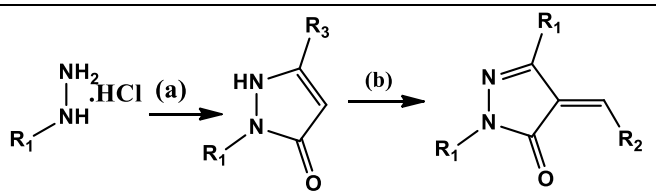

(68) $\mathrm{R}_{1}=$ Aryl; $\mathrm{R}_{2}=$ Benzylidene; $\mathrm{R}_{3}=\mathrm{Me}, \mathrm{Et}, \mathrm{CF}_{3}, \mathrm{COOH}$

Scheme 22. Synthesis of dialkoxybenzylidene pyrazolones (68): (a) $\mathrm{R}_{3} \mathrm{COCH}_{2} \mathrm{CO}_{2} \mathrm{Me}, \mathrm{EtOH} / \mathrm{AcOH} / \mathrm{K}_{2} \mathrm{CO}_{3}-\mathrm{EtOH}$, reflux (b) $\mathrm{R}_{2} \mathrm{CHO}, \mathrm{H}_{2} \mathrm{O}$, reflux or $\mathrm{LiOH}, \mathrm{MeOH} / \mathrm{THF} / \mathrm{H}_{2} \mathrm{O}$

Chiral synthesis of oxindole-pyrazolones (69) from $N$-phenylpyrazolones and isatinderived $N$-Boc ketimines with excellent yield $(92-95 \%)$ and enantioselectivity (59-99 \% ee) (Scheme-23) [143].

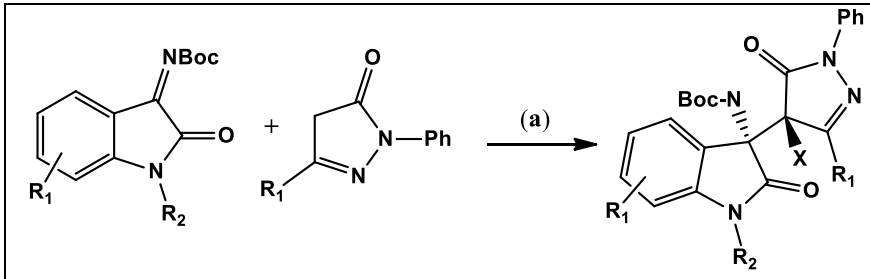

(69), $\mathrm{X}=\mathrm{F}, \mathrm{Cl}, \mathrm{Br}, \mathrm{SPh}$

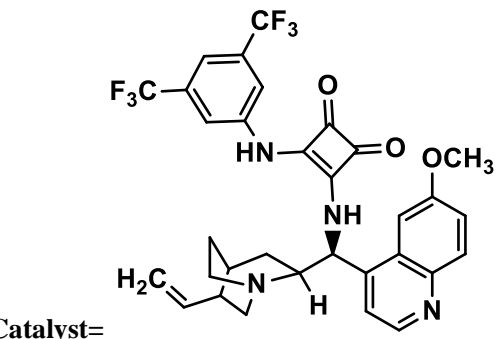

Scheme 23. Synthesis of oxindole-pyrazolones (69): (a) i. Cat. (0.5 mol \%), DCM, $25{ }^{\circ} \mathrm{C}$, ii. NFSI, $\mathrm{K}_{2} \mathrm{CO}_{3}, \mathrm{DCM}, 25{ }^{\circ} \mathrm{C}$ or $\mathrm{NCS} / \mathrm{NBS} 25{ }^{\circ} \mathrm{C}$ or $\mathrm{N}$-phenylthiophthalimide, $\mathrm{K}_{2} \mathrm{CO}_{3}, 25^{\circ} \mathrm{C}$.

Parekh et al. synthesized heterocyclic-fused-pyrazolones (70a-j) from nitroalkenes and pyrazolo esters via DABCOcatalyzed Michael addition and reductive ring-closing strategy with a yield of 74-92\% (Scheme-24) [144]<smiles>[R2]C=C([R2])[N+](=O)[O-]</smiles>

\begin{tabular}{|c|c|c|c|c|c|c|c|c|c|}
\hline Compd & $\mathbf{R}_{1}$ & $\mathbf{R}_{2}$ & $\mathbf{R}_{\mathbf{3}}$ & $\mathbf{n}$ & Compd & $\mathbf{R}_{\mathbf{1}}$ & $\mathbf{R}_{\mathbf{2}}$ & $\mathbf{R}_{3}$ & $\mathbf{N}$ \\
\hline $70 a$ & $\mathrm{Ph}$ & $\mathrm{H}$ & $\mathrm{Ph}$ & 0 & $70 f$ & $\mathrm{Ph}$ & $\mathrm{Me}$ & $\mathrm{Ph}$ & 0 \\
\hline $70 \mathrm{c}$ & $\left(p-\mathrm{MeCO}_{2}\right) \mathrm{Ph}$ & $\mathrm{H}$ & $\mathrm{Ph}$ & 0 & $70 \mathrm{~h}$ & $\mathrm{Ph}$, & $\mathrm{H}$ & $\mathrm{Me}$ & 0 \\
\hline 70e & 2-Thienyl & $\mathrm{H}$ & $\mathrm{Ph}$ & 0 & $\mathbf{7 0 j}$ & 1,2-Naphtho, & 1,2-Naphtho & $\mathrm{Ph}$ & 1 \\
\hline
\end{tabular}

Scheme 24. Synthesis of heterocyclic-fused-pyrazolones (70a-j): (a) DABCO, DCM, r.t., 4h, (b) Zn, AcOH, r.t., 2 h, (c) Toluene : AcOH (3:2), $120{ }^{\circ} \mathrm{C}, 24$ h. 
Synthesis of $N$-aryl benzylidenepyrazolone (71) using $\mathrm{SiO}_{2} / \mathrm{Al}_{2} \mathrm{O}_{3}$ under solvent free microwave assisted conditions with $80-81 \%$ yield of product [145].

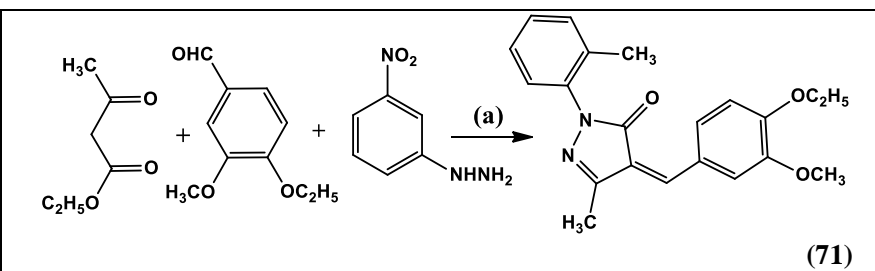

Scheme 25. Synthesis of $N$-aryl benzylidenepyrazolone (71): (a) $\mathrm{SiO}_{2} / \mathrm{Al}_{2} \mathrm{O}_{3}$, Solvent-free, MW, 420W, $10 \mathrm{~min}$

The most wide method synthesis for pyrazol-5-one is the condensation of dicarbonyl compounds with hydrazines. The reaction of arylthiosemicarbazide and ethyl acetoacetate afforded 1-arylthioanilido-3-methylpyrazolone [107]

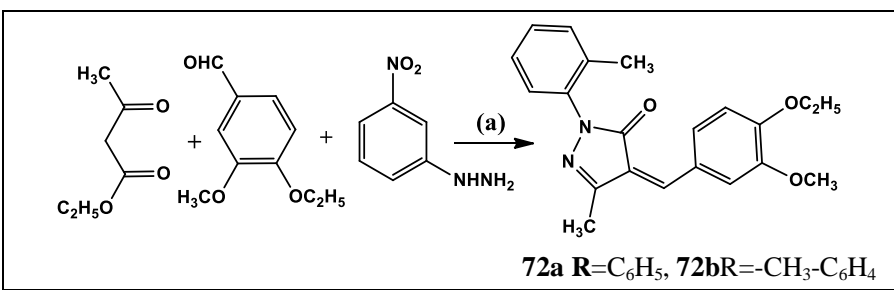

Scheme 26. Synthesis of pyrazol-5-one compound.

Synthesized different derivatives with pyrazolone as the basic heterocyclic nucleus, treated ethyl acetoacetate with thiosemicarbazide in ethanol, and triethylamine afforded the condensation product ethyl 3-(2-carbamothioylhydrazono)butanoate, not the cyclized form 73. The treatment of arylthiosemicarbazide with phencyl bromide in ethanol and fused sodium acetate afforded 3-methyl-1-(4phenylthiazol-2-yl)-1H-pyrazol-5(4H)-one 74, scheme 27 [146-149].

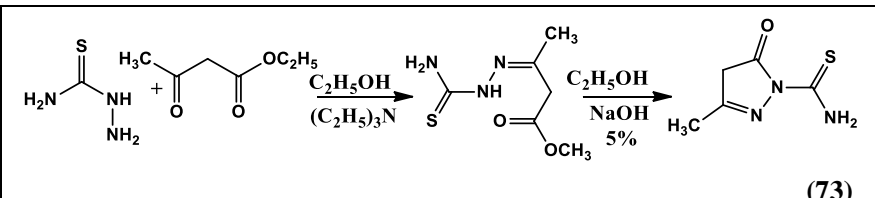

Scheme 27. Synthesis of compound 73.

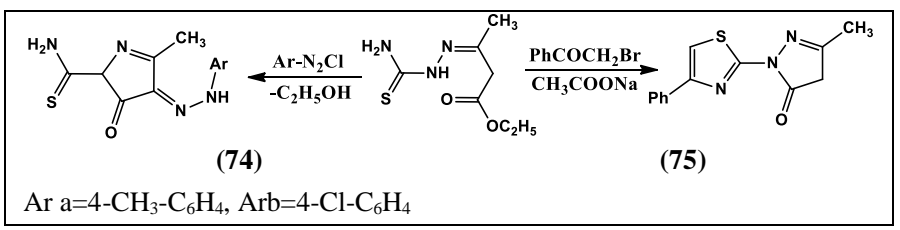

Synthesis 28. Synthetic pathways for compounds 74 and 75 .

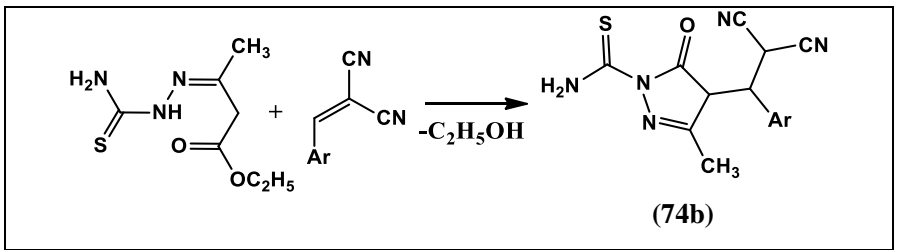

Scheme 30: synthesis of pyrazolone derivative.

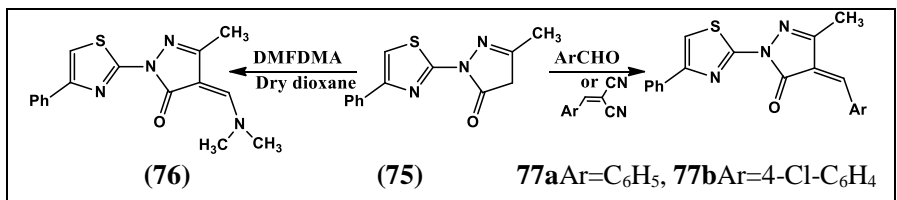

Scheme 31: synthesis of substituted pyrazolone compounds.

\section{DISCUSSION}

Pyrazolone derivatives are believed to be involved in various biochemical and physiological reactions and thus scientific research programs are continuously pouring in concerning improvised synthetic techniques to prepare numerous pyrazolone derivatives. From the last decade, a lot of work is going on the pyrazolone nucleus. Scientists have developed various new compounds related to this moiety and tested them for their different pharmacological activities to get a molecule of desired pharmacological activities. An intensive literature survey including the methods of synthesis for various pyrazolone derivatives has been carried out, as the pyrazolone derivatives have been of interest to medicinal chemists for their wide range of biological activities [150-154]. Pyrazolones are an important class of heterocyclic compounds that occur in many drugs and is an anti-inflammatory agent used in the treatment of arthritis and other musculoskeletal and joint disorders.

Pyrazolones are a biologically important group of compounds having diverse biological activities like antibacterial, antifungal, anti-inflammatory, antidiabetic, analgesic, antipyretic, immunosuppressive agents, hypoglycemic, antiviral, antineoplastic activity and other biological activities [155-159]. Although earlier many of pyrazolone derivatives were associated with adverse effects such as agranulocytosis, skin rashes, and blood dyscariasis, etc. that may have halted peer progress for some time but peer extensive and versatile profile have made the pyrazolones favorites for newer drug development. Keeping in view the increasing importance of these derivatives, a need to review the progress regarding pyrazolone was felt.

\section{CONCLUSION}

The pyrazolone is an important heterocyclic skeleton that can be modified into a variety of derivatives. For more than a century, heterocyclic compounds have constituted one of the largest areas of research in organic chemistry. Pyrazolones are the versatile active heterocyclic which is of immense importance biologically and industrially. Pyrazolone nucleus is present as a core structural component in an array of drug categories. Several strategies have been developed to synthesize the pyrazolone derivatives for different proposes. Here, several synthetic strategies are described for the development of pyrazolone derivatives along with their biological activities. This article will help to design synthetic schemes and their possible biological applications. Pyrazolone derivatives are gaining importance through their diverse biological and pharmacological activities such as antioxidant, antidiabetic, anticancer, anticonvulsant, hepatoprotective, neuroprotective, antiviral, antithrombotic, antimicrobial, myocardial and vascular injury, ischemia, myocardial infarction, atherosclerosis, and radioprotective and other biological effects. This review reflects the contribution of pyrazolone heterocycle to the development of society from a biological point of view and the understanding of life processes as well as may enlighten the medicinal chemists who are aspiring to discover a versatile drug candidate for the benefit of mankind.

\section{ACKNOWLEDGEMENT}

We are very thankful to the Department of pharmaceutical Chemistry, Himalayan Institute of Pharmacy and Research, Dehradun, Uttarakhand, India, and Department of Pharmaceutical Chemistry, Faculty of Pharmacy, Northern Border University, Rafha, Saudi Arabia for providing necessary facilities.

\section{COMPLIANCE WITH ETHICAL STANDARDS}

This article does not contain any studies involving human participants performed by any of the authors and does not contain any studies involving animals performed by any of the authors.

\section{CONFLICT OF INTEREST}

The authors declare that they have no conflicts of interest.

\section{REFERENCES}

1. Lednicer, D., and Mitscher, L.A. In Organic Chemistry of Drug Synthesis; Wiley Interscienc: New York, 1997, 1, 226.

2. Lalit, K., Chandresh, T., Vivek, S. Inter. J. Res. Pharm. \& Sci., 2012, 2(2), $13-22$.

3. Yoon, S., Choi, B., Rahman, M.M., Kumar, S., Kabir, S.M.M., Koh, J. Materials, (Basel), 2019, 12(24), 4209. 
4. Idemudia, O.G., Sadimenko, A.P., Hosten, E.C. Inter. J. Mol. Sci., 2016, 17(5), 687.

5. A-mata, E., Bland, N. D., Campbell, R.K., Pollastri, M.P. Tetrahedron Lett., 2015, 56(21), 2832-2835.

6. Idemudia, O.G., Sadimenko, A.P., Afolayan, A.J., Hosten, E.C. Bioinorg. Chem. Appl., 2015, 717089.

7. Stefaniak, J., Lewis, A.M., Conole, D., Galan, S.R.G., Bataille, C.J.R., Wynne, G.M., Castaldi, M.P., Lundbäck, T., Russell, A.J., Huber, K.V.M. ACS Chem. Biol., 2018, 13(10), 2849-2854.

8. Romina, N., Camilla, F., Serena, M., Elisabetta, C., Tiziano, T., Ilaria, M.M., Francesco, D.L., Delia, P., Raquel, T., Alberto, C., Riccardo, P., Pierangelo, G., Silvia, B. Br. J. Pharmacol., 2015, 172(13), 3397-3411.

9. Paul, C.T., Kevin, T.Z., Susan, G.F., Isaac, T.S., Radhia, B., Jason. M., Donald, R.K., Richard, I.M., Richard, B.S. ACS Chem. Neurosci. 2014, 5(9), 823-829.

10. Victor, H., Yung-Hyo, K., Tino, W.S., Danielle, B., Nouri, N., Kyung, W.J. Bioorg. Med. Chem. Lett., 2010, 20(22), 6854-6857.

11. Yinan, Z., Radhia, B., He, H., Tian, C., Cindy, V., Richard, I.M., Donald, R.K., Richard, B. S. J. Med. Chem., 2013， 56(6)， 2665-2675.

12. Sumit S,M., Michele, S., Smitha, S., Jeff, P., Uyen, L., Taylor, K.L., Vid, L., Angel, T., Aaron, D. J. Med. Chem., 2014, 57(8), 3283-3294.

13. Mei, Z., Zhi-fu, X., Run-tao, Z., Da-kai, C., Min, G., Shi-chao, C., Yangming, Z., Xin-wen, Z., Yan-yan, Y., Jia, L., Fa-jun, N., Jing-ya, L. Acta Pharmacol. Sin., 2018, 39(10), 1622-1632.

14. Camila, M.-G., Daniela, C.-R., Francisco, A.-C., Iván, P., Eduardo, F., Julio, C. PLoS One, 2017, 12(12), e0189213.

15. Ravindranath, L.K., Kumar, E.V.S., Srikanth, K., Spoorthi, Y.N., Phebe, P. Life Sci. Chem., 2012, 2(3), L-145.

16. Himly, M., Jahn-Schmid, B., Pittertschatscher, K., Bohle, B., Grubmayr, K., Ferreira, F., Ebner, H., and Ebner, C. J. Allergy Clin. Immunol., 2003, 111, 882-888.

17. Al-Haiza, M.A., El-Assiery, S.A., Sayed, G.H. Acta Pharm., 2001, 51, 251-261.

18. Castagnolo, D., Manetti, F., Radi, M., Bechi, B., Pagano, M., De Logu, A., Meleddu, R., Saddi, M., and Botta, M. Bioorg. Med. Chem., 2009, 17(15), 5716-5721.

19. Radi, M., Bernardo, V., Bechi, B., and Castagnolo, D. Tetrahedron Lett., 2009, 50, 6572-6575.

20. Moreau, F., Desroy, N., Genevard, J.M., Vongsouthi, V., Gerusz, V., Le Fralliec, G., Oliveira, C., Floquet, S., Denis, A., Escaich, S., Wolf, K., Busemann, M., and Aschenbrenner, A. Bioorg. Med. Chem. Lett., 2008, 18(14), 4022-4026.

21. Sauzem, P.D., Machado, P., Rubin, M.A., da S Sant'anna, G., Faber, H.B., de Souza, A.H., Mello, C.F., Beck, P., Burrow, R.A., Bonacorso, H.G., Zanatta, N., and Martins, M.A. Eur. J. Med. Chem., 2008, 43(6), $1237-$ 1247.

22. Pasha, F.A., Muddassar, M., Neaz, M.M., and Cho, S.J. J. Mol. Graph. Model., 2009, 28(1), 54-61.

23. Rosiere, C.E., and Grossman, M.I. Science, 1951, 113(2945), 651-653.

24. Bailey, D.M., Hansen, P.E., Hlavac, A.G., Baizman, E.R., Pearl, J., DeFelice, A.F., Feigenson, M.E. J. Med. Chem., 1985, 28(2), 256-260.

25. Chauhan, P.M., Singh, S., and Chatterjee, R.K. Indian J. Chem. Sect. B, 1993, 32, 858-861.

26. Shestopalov, A.M., Emelyanova, Y.M., Shestopalov, A.A., Rodinovskaya, L.A., Niazimbetova, Z.I., and Evans, D.H. Tetrahedron, 2003, 59, 4917496.

27. Guangfei, L., Lang, Li., Dianzeng, J., and Kaibei, Y. Struct. Chem., 2005, 16, 135-140.

28. Fiordalisi, F.M. United State Patent Office. Patented Jan. 19, 1965, $3,166,475$

29. Brune, M.D., Acute Pain, 1997, 1(1), 33-40.

30. Knorr, L. Ber Dtsch Chem. Ges., 1883, 16, 2597.

31. Rainsford, K.D. J. Physiol., 2001，95, 11-19.

32. Diptesh, S., Rishi, K., Ashoke, S., Prakas, R.M., Vishnu Ji R. Tetrahedron Lett., 2005, 46(22), 3807-3809.

33. Higashi, Y., Jitsuikia, D., Chayamab, K., Yoshizumia, M. Recent Patents on Cardiovas Drug Disc., 2006, 1, 85-93.

34. Mariappan. G., Saha, B.P., Bhuyan, N.R., Bharti, P.R., Deepak, K. J. Adv. Pharm. Tech. Res., 2010, 1(2), 260-267.
35. Baciu-Atudosie, L., Ghinet, A., Belei, D., Gautret, P., Rigo, B., Bicu, E Tetrahedron Lett., 2012, 53, 6127-6131.

36. Ochei, J., Kolhatkar, A. Medicinal Laboratory Science-Theory and Pracitces; Tata McGrow-Hill Publishing Co. Ltd.: New Delhi, 2000, 808818.

37. Isloor, A.M., Kalluraya, B., Sridhar Pai, K. Eur. J. Med. Chem., 2010, 45(2), 825-830.

38. Chandrakantha, B., Shetty, P., Nambiyar, V., Isloor, N., Isloor, A.M. Eur. J. Med. Chem., 2010, 45(3), 1206-1210.

39. Sankappa Rai, U., Isloor, A.M., shetty, P., Vijesh, A.M., Prabhu, N., Isloor, S., Thiageeswaran, M., Fun, H.K. Eur. J. Med. Chem., 2010, 45(6), $2695-$ 2699.

40. Vijesh, A.M., Isloor, A.M., Isloor, S.K., Shivananda, K.N., Shyma, P.C., Arulmoli, T. Der. Pharm. Chem., 2011, 3, 454-463.

41. Yoshida, H., Yanai, H., Namiki, Y., Fukatsu-Sasaki; K., Furutani, N., Tada, N. CNS Drug Rev., 2006, 12(1), 09-20.

42. Yagi, H., Horinaka, S., Matsuoka, H. J. Cardiovasc. Pharmacol., 2005, 46(1), 46-51.

43. Hassan, A.E., Moustafa, A.H., Tolbah, M.M., Zohdy, H.F., Haikal, A.Z. Nucleosides Nucleotides Nucleic Acids, 2012, 31(11), 783-800.

44. Mariappan, G., Saha, B.P., Sutharson, L., Singh, A., Garg, S., Pandey, L., Kumar, D. Saudi Pharm. J., 2011, 19(2), 115-22.

45. Saidachary. G., Prasad, K.V., Divya, D., Singh, A., Ramesh, U., Sridhar, B., Raju, B.C. Eur. J. Med. Chem., 2014, 76, 460-469.

46. Wang, X.H., Wang, X.K., Liang, Y.J., Shi, Z., Zhang, J.Y., Chen, L.M., Fu, LW. Chin. J. Cancer, 2010, 29(12), 980-987.

47. Rosiere, C.E., Grossman, M.I. Science, 1951, 113(2945), 651-653.

48. Singh, B.K., Sachan, N., Chawla, P. Curr. Bioact. Comp., 2013，9(4), 279 287.

49. Harmon, R.E., Geller, B.L., Gupta, S.I., Herbert, M.H., Chitharanjan, D. J. Pharm. Sci., 1970, 59(7), 1031-1033.

50. Basaif, S.A., Hassan, M.A., Gobouri, A.A. Dyes Pigm. 2007, 72, 387-391. 51. Ho, Y.W. Dyes Pigm., 2005, 64, 223-230.

52. Kakiuchi, Y., Sasaki, N., Satoh-Masuoka, M., Murofushi, H., MurakamiMurofushi, K. Biochem. Biophys. Res. Commun., 2004, 320(4), 1351-1358.

53. Tiwari, R.K., Mishra, R.K., Srivastava, S.K., Bahel, S.C. Pesticide Res. J., 1990, 2(1), 24-27.

54. Hadi, V., Koh, Y.-H., Sanchez, T.W., Barrios, D., Neamati, N., Jung, K.W. Bioorg. Med. Chem. Lett., 2010, 20(22), 6854-6857.

55. Datar, P.A., Jadhav, S.R. Int. J. Med. Chem., 2015, 670181.

56. Idrees, G.A., Aly, O.M., Abuo-Rahma, G.D., Radwan, M.F. Eur. J. Med. Chem., 2009, 44(10), 3973-3980.

57. Tomkins, P.T., Cooper, K.L., Titchmarsh, S.A., Appleby, P., Webber, D.G. Int. J. Immunopharmacol., 1995, 17(5), 357-366.

58. Siva, K.K., Rajasekharan, A. Inter. J. Res. Pharm. \& Chem., 2012, 2(2), 327-337.

59. Devnath, H.P., Islam, M.R. Bangladesh J. Pharmacol., 2010, 5, 30-33.

60. Rahat, K., Imam, U., Alam, M., Sultan, D. J. Bangladesh Parmacol. Soc., $2008,3,27-35$.

61. Jelich, K., Kraemer, W., Brandes, W., Haenssler, G., Reinecke, P. U.S. Pat. 1987, 4666933 A

62. Kakiuchi, Y., Sasaki, N., Satoh-Masuoka, M., Murofushi, H., MurakamiMurofushi, K. Biochem. Biophys. Res. Commun., 2004, 320(4), 13511358.

63. Tripathy, R., Ghose, A., Singh, J., Bacon, E.R., Angeles, T.S., Yang, S.X., Albom, M.S., Aimone. L.D., Herman, J,L., Mallamo, J.P. Bioorg. Med. Chem. Lett., 2007, 17(6), 1793-1798.

64. Gupta, P., Gupta, J.K. Open Chem. J., 2016, 3, 17-24.

65. Tudor, R., Simona, P., Veronica, L., Carmen, C., Raluca, C. Molecules, 2006 , 11.

66. Min, J.S., Jung, K.K., Bum, S.S., Bo, G.S., Zaesung, N., Hyae, G.C., KwangRok, K., Young, S.S., Hyoung, R.K. Bull. Korean Chem. Soc., 2004, 25(8), 1121.

67. Mariappan, G., Saha, B.P., Sutharson, L., Ankit., Garg, S., Pandey, L., Kumar, D. J. Pharm. Res., 2010， 3(12), 2856-2859.

68. Mahmoud, M.M., Ibrahim, S., Abdel, H. J. Chin. Chem. Soc., 2012, 59, $72-$ 80

69. Kumar, S.K., Rajasekharan, A. Inter. J. Res. Pharm. \& Chem., 2012, 2(2), 327-337. 
70. Parmar, N., Shashikant, T., Rikin, P., Barad, H., Jajda, H., Thakkar, V. J. Saudi Chem. Soc., 2015, 19, 36-41.

71. Yamamoto, Y., Kuwahara, T., Watanabe, K. Redox Report, 1996, 2, $333-$ 338.

72. Kazutoshi, W., Yasuhiro, M., Katsuhiko, I., Toshiaki, W., Satoshi, Y., Hiroyoshi, N. Redox Report, 2003, 8.

73. Soni, J.P., Sen, D.J., Modh, K.M. J. Appl. Pharm. Sci., 2011, 1(04), 115120.

74. Mariappan, G., Saha, B.P., Sutharson, L., Haldar, A. Ind. J. Chem., 2010 49B, 1671-1674.

75. Amir, M., Kumar, S. Ind. J. Chem., 44B, 2005, 2532-2537.

76. Mariappan, G., Saha, B.P., Sutharson, L., Haldar, A. Ind. J. Chem., 2010, 49B, 1671-1674.

77. Georgewill, O.A., Georgewill, U.O., Nwankwoala, R.N.P. The Internet J. Pharmacol., 2009, 7(1), doi: 10.5580/21fc,

78. Silva, S.L.D., Comar, J.M., Oliveira, K.M.T., Bezerra, E.R.M., Calgarotto, A.K., Baldosso, P.A., Veber, C.L., Villar, J.A.F.P., Oliveira, A.R.M., Marangoni, S. Inter. J. Quant. Chem., 2008, 108 (13), 2576-2585.

79. Nishiyama, T., Ogawa, M. Acta. Anaesthesiol. Scand., 2005, 49(2), 147151.

80. Brogden, R.N. Drugs, 1986， 32(4)， 60-70.

81. Graham, G.G., Scott, K.F. Inflammopharmacol., 2003， 11，401-413.

82. Bentur, Y., Cohen, O. J. Toxicol. Clin. Toxicol., 2004, 42, 261-265.

83. Lalit, K., Chandresh, T., Vivek, S. Inter. J. Res. Pharm. \& Sci., 2012, 2(2), 13-22.

84. Doretto, M.C., Garcia-Cairasco, N., Pimenta, N.J.G., Souza, D.A., Tatsuo, M.A.K.F. Neuro. Report., 1998, 9(10), 2415-2421

85. Abdel-Aziz, M., Abuo-Rahma, G.E.-D.A., Hassan, A.A. Eur. J. Med. Chem., 2009, 44, 3480-3487.

86. Minhaz, U., Tanaka, M., Tsukamoto, H., et al., Free Radic. Res., 1996, 24, 361-3677.

87. Tsujita, K., Shimomura, H., Kawano, H., et al., Am. J. Cardiol., 2004, 94, 481-484.

88. Yanagisawa, A., Miyagawa, M., Ishikawa, K., Murota, S. Inter. J. Angiol., 1994, 3, 12-15.

89. Guniz, K., Sevim, R., Habibe, E., Muammer, K., Ekinci, A.C., Vidin, A. Euro. J. Med. Chem., 2000, 35(7-8), 761-771.

90. Ogasawara, K., Inoue, T., Kobayashi, M., Endo, H., Fukuda, T., Ogawa, A. Neurosurgery, 2004, 55, 1060-1067.

91. Kuçukguze, G., Rollas, S., Erdeniz, H., Kiraz, M., Ekinci, A., Cevdet, V.A. Euro. J. Med. Chem., 2000, 35(7-8), 761-771.

92. Oishi, R., Itoh, Y., Nishibori, M., Watanabe, T., Nishi, H., Saeki, K. Stroke, 1989, 20, 1557- 1564 .

93. Ross, R. N. Engl. J. Med.,1999， 340， 115-126.

94. Evstropov, A.N., Yavorovskaya, V.E., Vorobev, E.S., Khudonogova, Z.P., Medvedeva, S.G., Filimonov, V.D., Prishchep, T.P., Saratikov, A.S. Pharm. Chem. Jour., 1992, 26(5), 426-430.

95. Yuan W.J., Yasuhara, T., Shingo, T., Muraoka, K., Agari, T., Kameda, M., Uozumi, T., Tajiri, N., Morimoto, T., Jing, M., Baba, T., Wang, F., Leung, H., Matsui, T., Miyoshi, Y., Date, I. BMC Neurosci., 2008, 9, 75.

96. Takeshi, M., A-Hon, K., Katsushige, T., Zeyu, Q., Tadayoshi, O., Yasuo, K. Shock, 2008, 30(2), 212-216.

97. Hady, S. Br. Med. Jour., 1973, 1(5855), 744.

98. Resta, O., Foschino-Barbaro, M.P., Carnimeo, N., Bavoso, P., Picca, V. Respiration, 1984, 46, 121-127.

99. Ramajayam R, Tan KP, Liu HG, Liang PH. Bioorg \& Med Chem, 2010; 18 : 7849-7854.

100.Kees KL, Caggiano TJ, Steiner, K. E, Fitzgerald, J. J, Kates M. J., Christos T. E, Kulishoff J. M, Moore R. D, McCaleb M. L. J. Med. Chem. 1995, 38 , 617-628.

101.Kees, K.L., Fitzgerald, J.J., Steiner, K.E., Mattes, J.F., Mihan, B., Tosi, T., Mondoro, D., McCaleb, M.L. J. Med. Chem., 1996, 39, 3920-3928.

102.Das N., Verma, A., Shrivastava, P.K., Shrivastava, S.K. Ind. J. chem., 2008, 47B, $1555-1558$.

103.Yoshida, H., Sasaki, K., Namiki, Y., Sato, N., Tada, N. Atherosclerosis, 2005, 179, 97-102.

104.Kees, K.L., Caggiano, T.J., Steiner, K.E., Fitzgerald, J.J., Kates, M.J., Christos, T.E., Kulishoff, J.M., Moore, R.D., McCaleb, M.L. J. Med. Chem., 1995, 38, 617-628

105.Piskarev, A.V., Nesterenko, V.S. Bull. Exp. Bio. Med., 1975, 80(1).
106.Dhawan, S., Narang, R., Khatik, G.L., Chopra, H.K., Nayak, S.K. J. Chem. \& Pharm. Res., 2016, 8(5), 969-981.

107.Mousa, S.AS., Ishak, E.A., Bakheet, M.E.M., Abu-Shanab, F.A. Elixir Org. Chem., 2015, 89, 36854-36859.

108.Brana, M.F., Gradillas, A., Ovalles, A,G., Lopez, B., Acero, N., Llinares, F., Mingarro, D.M. Bioorg. Med. Chem. 2006, 14(1), 09-5.

109.Castagnolo, D., De Logu, A., Radi, M., Bechi, B., Manetti, F., Magnani, M. Supino, S., Meleddu, R., Chisu. L., Botta, M. Bioorg. Med. Chem., 2008, 16 (15), 8587-8591.

110.Burja, B., Kocevar, M., Polanc, S. Tetrahedron, 2009, 65(42), 8690-8696. 111.Burja, B., Kocevar, M., Polanc, S. Bioorg. Med. Chem., 2010, 18(7), $2375-$ 2387.

112.Akondi, A.M., Kantam, M.L., Trivedi, R., Bharatam, J., Vemulapalli, S.P.B., Bhargava, S.K., Buddana, S.K., Prakasham, R.S. J. Mol. Catal. A. Chem., 2016, 411, 325-336.

113.Bao, X., Wei, S., Zou, L., Song. Y., Qu, J., Wang, B. Tetrahedron: Asymm., 2016, 27(9-10), 436-441.

114.Rao, D.V.N., Prasad, A.R.G., Spoorthy. Y.N., Rao, D.R. Ravindranath, L.K. Ann. Pharm. Fr., 2014, 72(2), 101-106.

115.Kono, M., Proia, R.L. Exp. Cell Res., 2015， 333(2), 178-182.

116. Nakamura, T., Yonesu, K., Mizuno, Y., Suzuki, C., Sakata, Y., Takuwa, Y., Nara, F., Satoh, S. Bioorg. Med. Chem. 2007，15(10)，3548-3564.

117.Lavergne, K., Bongers, A., Betit, L., Beauchemin, A.M. Org. Lett., 2015 , 17(14), 3612-3615

118. Vereshchagin, A.N., Elinson, M.N., Korshunov, A.D., Egorov. M.P Mendeleev Commun., 2016, 26(1), 19-20.

119.Chande, M.S., Barve, P.A., Suryanarayan, V. J. Hetero. Chem., 2007, 44(1), 49-53.

120.Wu, S., Li, Y., Xu, G., Chen, S., Zhang, Y., Liu, N., Dong, G., Miao, C., Su, H., Zhang, W., Sheng, C. Eur. J. Med. Chem., 2016, 115, 141-147.

121.Amata, E., Bland. N.D., Campbell, R.K., Pollastri, M.P. Tetrahedron Lett., 2015, 56(21), 2832-2835.

122.Ceban, V., Olomola, T.O., Meazza, M., Rios, R. Molecules, 2015, 20 , $8574-8582$

123.Li; J.H., Feng, T.F., Du, D.M. J. Org. Chem., 2015, 80(22), 11369-11377.

124.Tu, X-C., Feng, H., Tu, M-S., Jiang, B., Wang, S-L., Tu, S.-J. Tetrahedron Lett., 2012, 53(25), 3169-3172.

125.Khloya, P., Kumar, P., Mittal, A., Aggarwal, N.K., Sharma, P.K. Org. Med. Chem. Lett., 2013, 3(1), 9 .

126.Kirscuke, K., Luize, G., Schmttz, E.J. Prakt. Chem., 1984, 326(3), 367373.

127.Chande, M.S., Joshi, R.M. Indian J. Chem., 1999，38B， 218-220.

128.El-Saraf, G.A., El-Sayed, A.M. Heteroat. Chem., 2003, 14(3), 211-217.

129.Karci, F., Ertan, N. Dyes Pigments, 2002， 55(2)，99-108.

130.Ho, Y.W. Dyes Pigments, 2005, 64(3), 223-230.

131.Khan, R., Uddin, M.I., Alam, M.S., Hossain, M.M., Islam, M.R. Bangladesh J. Pharmacol., 2008, 3(1), 27-35.

132.Huang, Y.-Y., Lin, H.-C., Cheng, K.-M., Su, W.M., Sung, K.-C., Lin, T.-P., Huang, J.-J., Lin, S.-K., Wong, F.F. Tetrahedron, 2009, 65(46), 9592 9597.

133.Ziarati, A., Safaei-Ghomi, J., Rohani, S. Ultrason. Sonochem., 2013, 20(4), 1069-1075.

134.He, Y., Bao, X., Qu, J., Wang, B. Tetrahedron: Asymm., 2015, 26(23), 1382-1387.

135.Mazimba, O., Wale, K., Loeto, D., Kwape, T. Bioorg. Med. Chem., 2014, 22(23), 6564-6569.

136.Trippier, P.C., Zhao, K.T., Fox, S.G., Schiefer, I.T., Benmohamed, R., Moran, J., Kirsch, D.R., Morimoto, R.I., Silverman, R.B. ACS Chem. Neurosci., 2014, 5(9), 823-829.

137.Patel, V.K.V., Sen, D.J. Int. J. Drug Dev. \& Res., 2010, 2(1), 203-210.

138. Yang, Z., Wang, Z., Bai, S., Liu, X., Lin, L., Feng, X. Org. Lett., 2011, 13(4), 596-599.

139.Liu, L., Siegmund, A., Xi, N., Kaplan-Lefko. P., Rex, K., Chen, A., Lin, J., Moriguchi, J., Berry, L., Huang, L., Teffera, Y., Yang, Y., Zhang, Y., Bellon, S.F., Lee, M., Shimanovich, R., Bak, A., Dominguez, C., Norman, M.H., Harmange, J.C., Dussault, I., Kim, T,S. J. Med. Chem., 2008, 51(13), 3688-3691.

140.Agejas, J., Ortega, L. J. Org. Chem., 2015， 80(12)， 6509-6514.

141.Liu, L., Zhong, Y., Zhang, P., Jiang, X., Wang, R. J. Org. Chem., 2012 , 77(22), 10228-10234. 
142.Hadi, V., Koh, Y.H., Sanchez, T.W., Barrios, D., Neamati, N., Junga, K.W. Bioorg. Med. Chem., 2010, 20(22), 6854-6857.

143.Bao, X., Wang, B., Cui, L., Zhu, G., He, Y., Qu, J., Song, Y. Org. Lett., 2015, 17(21), 5168-5171.

144.Parekh, N., Thomas, J., John, J., Kusurkar, R., De Borggraeve, W.M., Dehaen, W. J. Org. Chem., 2014, 79(11), 5338-5344.

145.Ma, R., Zhu, J., Liu, J., Chen, L., Shen, X., Jiang, H., Li, J. Molecules, 2010, 15, 3593-3601.

146. Pawar, R.A., Patil, A.A. Ind. J. Chem., 33B, 1994, 156-158.

147.Srivalli, T., Satish, K., Suthakaran, R. Inter. J. Innovative Pharm. Res., 2(4), 2011, 172-174.

148. Kobarkov, K.I., Rybina, I.I., Kelarev, V.I., Koloev, V.K. Chem. Heterocycl. Compd., 39 (6), 2003, 749-755.

149.Naik, C.G., Malik, C,M. Orient J. Chem., 2010, 26(1), 113-116.

150. Althagafi, I., El-Metwaly, N.M., Elghalban, M.G., Farghaly, T.A., Khedr, A.M. Bioinorg. Chem. Appl., 2018, 2727619. doi: 10.1155/2018/2727619

151.Yoon, S., Choi, B., Rahman, M.M., Kumar, S., Kabir, S.M.M., Koh, J. Materials., 2019, 12(24), 4209. doi: 10.3390/ma12244209.
152.Zhang, Y., Zhao, K.T., Fox, S.G., Kim, J., Kirsch, D.R., Ferrante, R.J., Morimoto, R.I., Silverman, R.B. J Med Chem., 2015, 58(15), 5942-5949.

153. Pei, L., He, S., Gao, J., Liao, H., Gao, H. Polymers, 2017, 9(7), 262. doi: 10.3390/polym9070262

154. Yepremyan, A., Mehmood, A., Brewer, S., Barnett, MM., Janesko, B.G., Akkaraju, G., Simanek, E.E., Green, KN. RSC Adv., 2018, 8(6), 30243035 .

155. Amata, E., Bland, N.D., Campbell, R.K., Pollastri, M.P. Tetrahedron Lett., 2015, 56(21), 2832-2835.

156.Mochona, B., Jackson, T., McCauley, D., Mazzio, E., Redda, K.K. J. Heterocycl. Chem., 2016, 53(6), 1871-1877.

157.Sweeney, N.L., Lipker, L., Hanson, A.M., Bohl, C.J., Engel, K.E., Kalous, K.S., Stemper, M.E, Sem, D.S., Schwan, W.R. Antibiotics, 2017, 6(1), 4. doi: 10.3390/antibiotics6010004

158.Mariappan, G., Saha, B.P., Sutharson, L., Singh, A., Garg, S., Pandey, L., Kumar, D. Saudi Pharm. J., 2011, 19(2), 115-122.

159.Sivakumar, K.K., and Rajasekaran, A. J. Pharm. Bioallied. Sci., 2013， 5(2), 126-135. 